IZA DP No. 8652

The Continued Search for the Solow Residual: The Role of National Entrepreneurial Ecosystem

Zoltan J. Acs

Saul Estrin

Tomasz Mickiewicz

László Szerb

November 2014 


\title{
The Continued Search for the Solow Residual: The Role of National Entrepreneurial Ecosystem
}

\author{
Zoltan J. Acs \\ London School of Economics \\ Saul Estrin \\ London School of Economics and IZA \\ Tomasz Mickiewicz \\ Aston University \\ László Szerb \\ University of Pecs
}

Discussion Paper No. 8652

November 2014

\author{
IZA \\ P.O. Box 7240 \\ 53072 Bonn \\ Germany \\ Phone: +49-228-3894-0 \\ Fax: +49-228-3894-180 \\ E-mail: iza@iza.org
}

\begin{abstract}
Any opinions expressed here are those of the author(s) and not those of IZA. Research published in this series may include views on policy, but the institute itself takes no institutional policy positions. The IZA research network is committed to the IZA Guiding Principles of Research Integrity.

The Institute for the Study of Labor (IZA) in Bonn is a local and virtual international research center and a place of communication between science, politics and business. IZA is an independent nonprofit organization supported by Deutsche Post Foundation. The center is associated with the University of Bonn and offers a stimulating research environment through its international network, workshops and conferences, data service, project support, research visits and doctoral program. IZA engages in (i) original and internationally competitive research in all fields of labor economics, (ii) development of policy concepts, and (iii) dissemination of research results and concepts to the interested public.
\end{abstract}

IZA Discussion Papers often represent preliminary work and are circulated to encourage discussion. Citation of such a paper should account for its provisional character. A revised version may be available directly from the author. 
IZA Discussion Paper No. 8652

November 2014

\section{ABSTRACT}

\section{The Continued Search for the Solow Residual: The Role of National Entrepreneurial Ecosystem ${ }^{1}$}

This paper introduces a new concept in addition to the traditional measures of stocks of capital, labor, human capital and knowledge, to understand the Solow Residual: National Entrepreneurial Ecosystem (NEE). The NEE construct is based on a methodology that combines institutions and human agency into an interdependent system, applying the configuration theory. We argue that NEE affects the efficiency by which inputs are turned into outputs shifting the production function. We use data from a representative global survey and institutional sources to test the model for a cross section of 62 counties over the period 20062010 to test this proposition.

JEL Classification: L26, J24, P3, O33

Keywords: growth, entrepreneurship, ecosystem, Solow residual, GEM

Corresponding author:

Zoltan J. Acs

Department of Management

LSE

Houghton St

London WC2A $2 \mathrm{AE}$

United Kingdom

E-mail: z.j.acs@Ise.ac.uk

\footnotetext{
${ }^{1}$ The authors would like to thank David B. Audretsch, Erik Stam, Erkko Autio, David Soskice. Any remaining errors are our own.
} 


\section{Introduction}

The Higgs boson, an elementary building block of modern physics, was first conceptualized in 1964 and its existence only confirmed in 2013. For economists, the inability to explain much of the cross country variation in output by inputs, termed the Solow residual, has - like the Higgs boson - consumed the efforts of a generation of scientists. Thus, Solow in 1957 in attempting to explain economic growth, could only account for about $13 \%$ of variation through the factors in his growth theory; the remaining residual accounted for 87 percent (see also Solow, 1956). To resolve this puzzle is important, because what lies behind the residual is presumed to be both a building block of the modern economy and essential to economic growth.

Solow (1957) acknowledged that only a part of economic growth was due to increasing capital and labor inputs; the remainder was caused by technological change. But explaining the determinants and measuring technological change, like the Higgs boson, has proven to be elusive. Understanding what would explain the Solow residual has stimulated much research: ideas have included human capital (education), research and development, patents, and industry structure (Barro, 1991; Barro and Sala-i-Martin, 1995; Romer, 1986; Aghion and Howitt, 1992). Thus the original notion of inputs generating outputs through an aggregate production function has been extended by more sophisticated measures of inputs, and more complex conceptualizations of the functional relationship and the factors underlying it. While it has not been difficult to explain how past knowledge creates new knowledge (standing on the shoulders of giants) it has been hard to find a strong relationship between the stock of knowledge and total factor productivity: “/.../ the long-run impact of the knowledge (patent) stock on TFP is small: Doubling the stock of knowledge is estimated to increase TFP only 10 percent in the long run. In other words, the results suggest that while $R \& D$ scientists and engineers greatly benefit from the knowledge and ideas discovered by prior research, the knowledge they produce seems to have had only a modest impact on measured total factor productivity (Abdih and Joutz, 2006, p. 244).”

So where do we look? In a recent paper Acs et al. (2014) built on Leibenstein (1968) to suggest that the answer lies in agency and the institutional structure of the society. Efficiency had first been linked to entrepreneurship by Schumpeter (1934); and that idea was developed by Liebenstein with his theory of X efficiency. More recently North (1990) stressed the importance of institutions in creating the incentive structure and the role of entrepreneurship to carry out the creation of new combinations of factors (see also: Estrin, Korosteleva, Mickiewicz, 2013). In other words, as Arrow (1962) pointed out, new knowledge has to be turned into economic knowledge, and that requires entrepreneurs (Braunerhjelm et al., 2010) and a suitable institutional structure that generates and supports agency.

How do we know this? In a rather little cited paper by Marshall Goldman we have a clue. Goldman (1970) replicated, more or less, the Solow results for the Soviet Union. What was different between the Soviet Union and the United States was not so much in the development of new technology but in the institutional structure. Goldman estimated that 
while the residual in the U.S. was around 87 percent, in the Soviet Union it was in the range of 20 percent. In other words, in the Soviet Union, capital and labor explained most of economic growth. Goldman predicted a decline in Soviet growth rates because neither capital nor labor alone could replicate the results from the past. Similarly Weitzman (1970) analyzed the Soviet experiment suggesting that the fundamental difference between the systems was in institutions and agency.

We therefore propose that the combination of agency and institutions represent the "missing link" in knowledge based growth models. The stronger the institutions, the more productive will be entrepreneurship, and the greater the impact of entrepreneurs on growth.

Entrepreneurs are the agents that, by commercializing innovations, provide the transmission mechanism transferring advances in knowledge into economic growth. However, even where entrepreneurial initiative is present, this process of transmission may be either hampered or facilitated by the institutional environment. The idea that institutions are pivotal in explaining the variation in economic growth, not accounted for by changes in factor inputs, was further analyzed by Acemoglu and Robinson (2013), and was extended explicitly to consider the inter-relationship between institutions and entrepreneurship by William Baumol (Baumol, 1990,1993; Baumol and Strom, 2007). Baumol argues that, even if all counties had similar supplies of entrepreneurship, economic growth and performance would differ as a consequence of heterogeneity in institutions and, as a consequence, the national incentive structure: countries with weak institutions will not create productive entrepreneurship but rather either unproductive or even destructive entrepreneurship (see also: Murphy, Shleifer and Vishny, 1993; Parker, 2009). Because the Soviet Union had weak market supporting institutions (Goldman 1970; Ofer, 1987) and poor incentives for wealth-creating entrepreneurship, much of its entrepreneurship was of the unproductive or even destructive type. Indeed, in the Soviet legal code, entrepreneurship of the productive type was seen as criminal activity.

The purpose of this paper is to consider the agency and the institutional context jointly and therefore to identify the role of the national entrepreneurial ecosystem (NEE) in economic growth. By NEE we mean the dynamic institutionally embedded interaction between individuals characterized by entrepreneurial attitudes abilities and aspirations, which drives the allocation of resources through the creation and operation of new ventures (Acs et al, 2014). We show that a measure of NEE can shed light on the hitherto unexplained part of variation in economic growth. This is a different version of the Solow residual, because the original was based exclusively on time series whereas we concentrate on cross country as well as inter-temporal differences. Yet extending the perspective is critical: cross country variation is necessary to understand the heterogeneity in NEE, and therefore to understand the determinants of growth. We estimate a growth model similar to that of Solow for a cross section of 66 countries between the years 2006 and 2010. The next section presents the theoretical background of the paper. The third section presents the methodology for identifying and measuring the National Entrepreneurial Ecosystem (NEE) while the fourth outlines the data used in our empirical counterpart and our findings. The summary is in the 
final section. Our findings support the view that NEE explains cross country differences in economic growth across different levels of development.

\section{Theoretical Background}

Solow (1957) proposed to separate variation in national output per head over time due to technical change from that due to changes in the availability of capital per head. The notion was understood to have "weak theoretical underpinnings" (Weitzman, 1970) but has been widely used since, because it represents one of the few ways to bring together the factors generating economic growth into a single framework. Thus, if $Q$ represents output and $\mathrm{K}$ and $\mathrm{L}$ represent capital and labor inputs in physical units, then the Solow aggregate production function can be written as:

$Q=F(K, L ; t)$

The variable $t$ for time appears in $F$ to allow for technical change. Here, the capital time series is perhaps the most problematic. Ideally what one would like to measure is the annual flow of capital services. Instead one must be content with a less utopian estimate of the stock of capital goods in existence.

It will be seen that Solow used the phrase "technical change" as a short-hand expression for any kind of shift in the production function. Solow estimates the function

$$
\frac{\dot{q}}{q}=\frac{\dot{A}}{A}+w_{k} \frac{\dot{k}}{k}
$$

using output per man hour, capital per man hour and the share of capital to disentangle technical change. Using American data for the period 1909-49 Solow concludes the following: technical change during that period was neutral on average; the upward shift in the production function was, apart from fluctuations, at a rate of about one per cent per year for the first half of the period and two per cent per head for the last half; Gross output per man hour doubled over the interval, with 87.5 per cent of the increase attributed to technical change, and the remaining to increased use of capital.

Technological change certainly plays a role in growth, but it is not a deus ex machina as implied in the Solow's framing; rather it is the product of endeavour, especially in the fields of science and engineering. The critical issue is to explain the mechanism enabling the transition from inventions to economic applications, which raise total factor productivity. The process is not automatic; in practice many inventions have never been commercialized, and many economies have been for long periods stagnant (Acemoglu and Robinson, 2013). This issue was already understood by Schumpeter (1934), who had the intuition that entrepreneurship is in some way associated with economic growth, though the evidence has been mixed (van Praag and Versloot, 2007; Carree and Thurik 2013). We argue that this is because we need a richer model that would account for the interaction between the entrepreneurs and the institutional context in which the value generating process occurs. Leibenstein's (1968) paper aimed to suggest a theory of the economy and entrepreneurship, 
in which entrepreneurship is a significant factor in the development process. According to Leibenstein, the theory of competition gives the impression that there is no need for entrepreneurship. If all inputs and outputs are marketed and their prices are known, and if there is a production function that relates inputs to outputs, then we can always predict the profit for any activity that transforms inputs into outputs. But one to one correspondence between sets of inputs and outputs is a very strong assumption. For example, contracts for labor are incomplete, the production function is not completely specified or known, and not all factors of production are marketed. As a result, a role for those who can handle uncertainty and for entrepreneurial agency in the process of economic growth emerges.

Related to this, we may distinguish between two types of entrepreneurial activity: routine and novel entrepreneurship. At one end of the spectrum, routine entrepreneurship is a type of management; at the other we have Schumpeterian (1934) or novel entrepreneurship. By routine entrepreneurship we mean the activities involved in coordinating and carrying ongoing concerns in which the parts of the production function they use are well known, and which operate in well-established and clearly defined markets. While some uncertainty remains, no new knowledge is being applied in the process. In contrast, by novel entrepreneurship (N-entrepreneurship) we mean the activities necessary to create or carry on an enterprise where not all the markets are well established or clearly defined, and in which the relevant parts of the production function are not known. In the case of $\mathrm{N}$ entrepreneurship, not all of the markets exist or operate well and the entrepreneur, if he/she is to be successful, must fill in for the market deficiencies. The gap filling and input completing capacities are the unique characteristics of the entrepreneur.

The main obstacle to our understanding of the entrepreneurial factor lies in the conventional theory of the production function. The basic culprits are the following assumptions: that the complete set of inputs is specified and known to all actual or potential firms in the industry, and that there is a fixed relation between inputs and outputs. The first assumption is implicit. The second assumption is explicit but it is rarely challenged. While in the U.S entrepreneurship was both abundant and easy to channel into productive uses, in countries like the Soviet Union it was not, because of institutional conditions, and this affected what could be produced with inputs based on given technology. We shall return to this point below.

The Solow residual highlights the issue of what constitutes technical change. According to Weitzman (1970, p. 686), writing about the Soviet economy, "It is at the point that our ignorance of what constitutes the residual becomes really annoying. What is it that should be pushed-increasing returns, labor skills, new innovations, optimal use of resources, better organization, or what?”

Jones and Romer (2009) identify two types of attempts to explain the Solow residual. The first is to include the stock of human capital in the production function for a cross section of countries. The switch from a time series for one country to a cross section has certain advantages. It allows us to look at different levels of development. Human capital increased in the United States steadily since 1880, measured for example by years of schooling. The 
cohort born in 1920 obtained just over 10 years of education, while the cohort born in 1980 went to school for 14 years. Another way to look at education is by the average years of education attained for the entire labor force in a given year. By this measure educational attainment has increased by about one year per decade. This increase contributes about 0.6 percentage point per year to U.S. growth, a significant fraction of our $2 \%$ per capita growth. Barro (1991) in a series of studies for almost 100 countries for the period 1960-1985 found that growth rate of real per capita GDP was (again) positively related to initial human capital, proxied by school enrolment rates, and negatively related to the initial (1960) level of real per capita GDP ( suggesting convergence). .

The more recent advance - endogenous growth theory - has been based on the emergence of research and development based models of growth, in the seminal papers of Romer (1990) and Aghion and Howitt (1992). This class of models explicitly aims to explain the role of technological progress in the growth process. R\&D based models view technology as the primary determinant of growth and treats it as an endogenous variable. These models add the stock of ideas to the traditional inputs of physical capital and labor. For example, Romer assumes a knowledge production function in which new knowledge is linear in the existing stock of knowledge, holding the amount of research labor constant. The idea is expressed in the simple model where the growth rate is proportional to $\AA / A=F(H, A)$ where $A$ is the stock of knowledge and $\mathrm{H}$ is the number of knowledge workers (R\&D). Because, in the Romer's model, long-run per capita growth is driven by technological progress, knowledge growth will increase long-run growth in the economy. While a country may be more prosperous because it allocates more resources to innovation, what determines the latter are essentially preferences. However, human capital and ideas are fundamentally different. Scale effects of ideas follow immediately from non-rivalry.

Jones and Romer (2009) suggested that progress in growth theory has been based on a tractable description of production possibilities based on a production function and a small list of inputs. Modern growth theory has added ideas, institutions, population and human capital. Physical capital has been pushed to the periphery. Summarizing the stylized facts they list the following:

- Increased flows of goods, ideas, finance and people — via globalization and urbanization-have increased the extent of the market for all producers and consumers.

- The variations in rate of growth of per capita GDP increases with the distance from the technological frontier (convergence) (Ibid., p. 3)

- Large income- and TFP differences persist. Differences in measured inputs explain less than half of the enormous cross country differences in per capita GDP (Ibid., p. $3)$.

- Poor countries are poor not only because they have less physical and human capital but because they use their inputs much less efficiently (Ibid., p. 18).

Jones and Romer conclude their paper with the observation that "there is very broad agreement that differences in institutions must be the fundamental source of the wide 
differences in growth rates observed for countries at low levels of income and for low income and TFP levels themselves.” (Ibid., p.20).

Following this, perhaps the most careful work on institutions has been carried out by Acemoglu, Johnson and Robinson (2005, p.385). In their survey of institutions as a fundamental cause of growth they write:

“...though this theoretical tradition is still vibrant in economics and has provided many insights about the mechanics of economic growth, it has for a long time seemed unable to provide a fundamental explanation of economic growth. As North and Thomas (1973, p.2) put it: "the factors we have listed (innovation, economies of scale, education, capital accumulation etc.) are not causes of growth; they are growth" (italics in original). Factor accumulation and innovation are only proximate causes of growth. In North and Thomas's view, the fundamental explanation of comparative growth is differences in institutions."

What exactly are institutions? North (1990, p.3) offers the following definition: "Institutions are the rules of the game in a society or, more formally, are the humanly devised constraints that shape human interaction....In consequence they structure incentives in human exchange, whether political, social or economic".

Of particular importance to growth are the economic institutions in society such as the structure of property rights and the presence of effective market frameworks. Economic institutions are important because they influence the structure of economic incentives. Without property rights, individuals will not have the incentive to invest in physical or human capital or adopt more efficient technologies. Economic institutions are also important because they help to allocate resources to their most efficient uses; they determine who gets profits, revenues and residual rights of control. As we noted for the Soviet Union, when markets were highly restricted and institutions sent the wrong signals, there was little substitution between labor and capital and technological change was minimal.

In a seminal paper Baumol (1990) proposed that countries' institutions create incentives and that the entrepreneurial talent is allocated to activities "with the highest private return, which need not have the highest social returns" (p. 506). Therefore, it is not possible to make inferences about externalities or overall social welfare effects based on generic measures of entrepreneurship. Universal welfare enhancing outcomes do not automatically follow from entrepreneurial activity; indeed such activities can generate questionable or undesirable effects. Entrepreneurial talent can be allocated among a range of choices with varying effects from wealth-creation to destruction of economic welfare. If the same actor can become engaged in such alternative activities, then the mechanism through which talent is allocated have important implications for economic outcomes (Desai, Acs and Weitzel, 2013), and the quality of this mechanism is the key criterion in evaluating a given set of institutions with respect to growth.

The comparison of the United States and the Soviet Union is a crucial one to understand how entrepreneurship and institutions combine to generate long term growth. Weitzman (1970) replicated the Solow results for the Soviet Union, a country where entrepreneurship existed 
only in illegal forms. What was different between the Soviet Union and the United States was not so much the generation of technology (they both had nuclear weapons and successful space programs) but the technological progress in economic applications. Goldman (1970) estimated that while the Solow residual in the U.S. was around 87 percent, in the Soviet Union it was in the range of 20 percent; in the Soviet Union additions to capital stocks and labor rather than technical progress explained most of economic growth.The importance of this example is that it enables us to isolate the impact of technological innovation from the institutional change, which in the case of Soviet Union was negligible. If there is low substitution of capital for labor and fixed technical coefficients of production, the residual will also be small.

What was the difference between the United States and the Soviet Union that drove these results? We follow many others, for example Hayek (1945) and Ofer (1987), in proposing that the answer rests upon the institutional system and the incentives that it created for agents; yet we differ in simultaneously stressing the role of entrepreneurs. In the United States institutions of private property and contract enforcement gave entrepreneurs the incentive to invest in physical and human capital, to combine inputs in ways to create new production functions, and to complete markets. In the Soviet Union, there was also entrepreneurship, but it took the unproductive and destructive forms (Aidis, Estrin, Mickiewicz, 2008).

We are therefore hypothesizing that it is entrepreneurs operating in productive institutional environments, in Baumol's sense, that provide the transmission mechanism from knowledge to economic growth. This leaves open the question of how to operationalize the features which make the economic system efficient in this process. If we accept that entrepreneurs are important for the efficient working of the system, to create or carry on an enterprise, where not all the markets are well established or clearly defined and in which the relevant parts of the production process are not completely known, an obvious way to approach the problem is to try to incorporate this into a production function. However this is not a simple task. We suggest that one way to test the efficiency of the process is to incorporate N-entrepreneurship into a system that combines institutions and agency (Acs, Autio and Szerb, 2014). Like Barro, who introduced human capital into the production function, we ask the question: to what extent does entrepreneurship (within a context of specific institutions) improve our explanation of the growth process, i.e. reduce the Solow residual? We cannot talk about institutions without talking about the individuals who will in fact be providing the valuecreating services.

The Romer model (1990) mentioned above gives us a starting point to frame investigation of sustainable rate of technological progress according to the national knowledge production function:

$\AA_{\mathrm{t}}=\delta \mathrm{H}_{\mathrm{A}, \mathrm{t}}^{\lambda} \mathrm{A}^{\phi}$ 
where $\delta$ denotes (average) research productivity, $\phi$ is the elasticity of research productivity of research workers, and $\lambda$ measures the elasticity of inter-temporal knowledge spillover from the past on current research efforts (standing on the shoulders of giants). Romer assumed a particular form of the knowledge production function. He imposed the restriction $\phi=1$ and $\lambda=1$. The key restriction made by Romer, however, is $\phi=1$. This makes $\AA$ linear in A, and hence generates growth in the stock of knowledge $\left(\AA / A\right.$ that depends on $L_{A}$ unit homogeneously:

$\AA / \mathrm{A}=\delta \mathrm{L}_{\mathrm{A}}$.

That is, the steady state growth rate of the stock of knowledge depends positively on the amount of labor devoted to research and development. This key result has important policy implications: Policies in a country which permanently increase the amount of labor devoted to research have a permanent long run effect on the growth rate of the economy.

The Romer paper captures two important relationships. First, long-run knowledge productions function where the flow of new knowledge depends positively on the existing stock of knowledge A, and the number of R\&D workers L. Second, a long run positive relationship between total factor productivity and the stock of knowledge in a particular national context is assumed. The results indicate the presence of strong inter-temporal knowledge spillovers. The elasticity of new knowledge with respect to existing stocks of knowledge $\phi$ is at least as large as unity. "However, the long-run impact of the knowledge stock on TFP is small: doubling the stock of knowledge in estimated to increase TFP by only 10 percent in the long run” (Abdih and Joutz, 2006, p. 244). The focus of the transmission mechanism between knowledge and TFP is needed to explain the parameter $\lambda$ above.

The primary breakthrough contributed by new growth theory is the recognition that investment in knowledge and human capital endogenously generate economic growth through the spillover of knowledge. However, endogenous growth theory does not explain how or why intra-temporal knowledge spillover occurs. TFP growth depends on the accumulation of knowledge and its diffusion through both incumbent organizations and entrepreneurial activity. It suggests further that entrepreneurs are a missing link in the conversion of new knowledge into economically relevant knowledge (Michelacci, 2003; Acs and Sanders, 2013). ${ }^{2}$

\footnotetext{
${ }^{2}$ Acs and Sanders (2013) develop a model that separates entrepreneurship from profitmotivated corporate R\&D aimed at improving existing production processes. The model embeds the core idea of agency into established knowledge-based growth models by enriching their knowledge structure. Generating knowledge and commercialization are two separate and costly activities, both of which need to be properly rewarded if the private sector is to engage in them.
} 


\section{National Entrepreneurial Ecosystems: a methodology}

There is a growing recognition that entrepreneurship theory focused only on the entrepreneur maybe too narrow. This is why researchers now discuss entrepreneurship ecosystems, support ecosystems or systems of entrepreneurship (Furerlinger, Funke and Fandle, 2014). While different approaches have different merits, none of the existing approaches addresses the dynamics of entrepreneurship ecosystems. The national entrepreneurial ecosystem (NEE) approach is based on three important premises that provide an appropriate platform for analysing entrepreneurial ecosystems. First, entrepreneurship is fundamentally an action undertaken and driven by agents on the basis of their incentives. Therefore, individual level data is needed to capture the dynamics of an entrepreneurial ecosystem. Second, the individual action is affected by a country's institutional framework for entrepreneurship. Therefore, country-level data on entrepreneurship framework conditions are also needed to capture the dynamics of an entrepreneurial ecosystem. Third, entrepreneurship ecosystems are complex, multifaceted structures in which many elements interact to produce systems performance, thus, the index method needs to allow the constituent elements to interact. Therefore, we define NEE as the dynamic institutionally embedded interaction between individuals' actions, which drives the allocation of resources.

This definition implies that NEE conceptualizes entrepreneurship as a trial-and-error process of knowledge spillovers and resource allocation that is driven by individuals and regulated by context, and that drives the allocation of resources toward productive use in the economy. In short, entrepreneurs crate new ventures to pursue perceived opportunities. However, it is impossible to prove in advance that a perceived opportunity is real-that is, if it will develop as expected - and the only way to test it is to mobilize resources. If the opportunity is not real, or if the country's framework conditions do not support the effective conversion of opportunities into new business growth, entrepreneurs will abandon the opportunity and put the resources to other uses. The net outcome of this dynamic process is an increase in the country's total factor productivity, a key determinant of economic growth.

The index approach was designed to captures the ability of a given country's entrepreneurial ecosystem (NEE) to contribute to total factor productivity and, therefore, to economic growth. This means that the NEE is fundamentally a quality index rather than a quantity index. The most important aspect of entrepreneurship from an economic perspective is not the quantity but the quality. We have built an empirical framework, Global Entrepreneurship \& Development Index (GEDI), to measure NEE and its consequences for economic growth (Acs, Autio Szerb, 2014). Perhaps the most important feature of it arises from the "penalty for bottleneck" approach, which stems from the notion that system elements coproduce system performance and bottleneck factors therefore may hinder the performance. For example, funding policies will be effective only if financing is a bottleneck that is inhibiting the creation and growth of new productive businesses. However, if the real bottleneck is entrepreneurial skills, providing additional money for new business may not improve the economy's entrepreneurial performance. Therefore, to produce real and lasting change in the 
dynamics of countries"' entrepreneurial entrepreneurship ecosystems, entrepreneurship policies need to address ecosystem bottlenecks in a coherent and coordinated way.

We borrow a term from biology to guide our modelling of agency and institutionsecosystem - to create the concept of a national entrepreneurial ecosystem. An ecosystem is defined as:

"An ecosystem is a community of living organisms in conjunction with the nonliving components of their environment, interacting as a system. These biotic and abiotic components are regarded as linked together through nutrient cycles and energy flows”. ${ }^{3}$

The concept of an ecosystem needs to be adapted from biology to economics. Accordingly, we combine both biotic (agents) data and abiotic (institutions) components and we develop a system that links institutions and agents through a NEE where each biotic and abiotic components are reinforced by the other at the country level. The system includes the stock of institutions and the stock of entrepreneurship and a theory as to how they interact through the flows of knowledge (nutrients) and human capital (energy). The nutrient of the economic ecosystem depends on knowledge, both the stock of knowledge and the flow of new knowledge as outlined in Romer (1990). This exogenous stock of knowledge provides the inputs into economic growth. However, turning knowledge into economic knowledge is not automatic (Arrow, 1962) and agency is needed to complete the production function and to fill in markets (Leibenstein, 1962). For example, contracts for labor are incomplete, the production function is not completely specified or known, and not all factors of production are marketed. As a result, a role for entrepreneurial agency in the process of economic growth emerges.

We recognize that country level entrepreneurship is a multifaceted phenomenon where individual capabilities and actions are contextualized by institutional incentives. This approach proposes that the building blocks (pillars) of entrepreneurial activity cannot be viewed in isolation. On the contrary, they constitute a system where the final outcome is moderated by the weakest performing pillar. Different economic ecosystems will have different outcomes in different parts of the world as the different agents and institutions interact. $^{4}$

Following Acs, Autio and Szerb (2014, p.479) we operationalize the country-level economic ecosystem by "entrepreneurial attitudes, entrepreneurial abilities, and entrepreneurial aspirations by individuals, which drives the allocation of resources through the creation and operation of new ventures." Utilizing these dimensions, we propose four levels indexbuilding: (1) variables, (2) pillars, (3) sub-indices, and finally (4) the super-index. All three sub-indices contain several pillars, which can be interpreted as quasi-independent building

\footnotetext{
${ }^{3}$ https://www.google.com/?gws_rd=ssl\#q=ecosystem August 4, 2014.

${ }^{4}$ The introduction of a foreign species (immigrants) into the system will cause dynamic changes.
} 
blocks. The sub-indices of attitudes, abilities, and aspiration constitute the entrepreneurship super-index. The structure of the index is in Table 1 while the detailed description of the variables can be found in the Appendix. 
Table 1. The Structure of the Global Entrepreneurship

Index

Attitudes Sub-Index

OPPORTUNITY

PERCEPTION

MARKET

AGGLOMERATION

OPPORTUNITY

STARTUP

SKILLS

POST-SEC

SKILL

EDUCATION

RECOGNITION

RISK

RISK

ACCEPTANCE

NETWORKING

CULTURAL

SUPPORT

Abilities Sub-Index

OPPORTUNITY

STARTUP

\section{TECHNOLOGY}

ABSORPTION

HUMAN

CAPITAL

COMPETITION

FREEDOM

TEA TECH

OPPORTUNITY ABSORPTION

TECH SECTOR

STAFF

TRAINING

$\mathrm{HIGH}$

EDUCATION

MARKET DOMINANCE

COMPETITION

\section{Aspirations Sub-Index}

\section{PRODUCT}

INNOVATION

$\begin{array}{ll} & \text { NEW } \\ \text { TECH TRANSFER } & \text { PRODUCT }\end{array}$
PROCESS

INNOVATION
$\mathrm{HIGH}$

GROWTH
INTERNATIONALIZATION

$$
\text { NEW BUSINESS }
$$

TECHNOLOGY STRATEGY
GAZELLE GLOBALIZATION
GERD

KNOW

ENTREPRENEUR

CORRUPTION

CAREE STATU

Note: The GEDI is a super-index made up of three sub-indexes, each of which is composed of several pillars. Each pillar consists of an environmental variable (odd columns) and an individual variable (even columns).
RISK CAPITAL DEPTH OF

CAPITAL

MARKET
INFORI

INVEST 
The methodology has been designed to capture these core features of the NEE in three ways. First, we approach country-level entrepreneurship as a systemic phenomenon, which is determined by the interaction between individual-level capabilities and initiations and country-level possibilities measured by institutional framework conditions. Second, we take into account that the marginal improvement of the fourteen pillars of entrepreneurship may differ; and equalizes the marginal effects over the pillars. This feature is vital for resource allocation optimization and improvement. Third, we respect the imbalance of the fourteen pillars in the country level and adjust scores according to the relative size and magnitude of the dis-harmonization.

This produces a multifaceted index that reflects the complexity of country-level entrepreneurial ecosystems. It measures 14 different aspects of entrepreneurship ecosystems that are organized into Attitudes, Abilities and Aspirations. Positive attitudes are needed so that competent individuals choose entrepreneurship over alternative occupations. The ability aspect reflects the quality of the resulting new ventures within their national context.

Aspirations reflect these ventures' potential to achieve rapid growth and high productivity.

Each pillar is measured as a composite of individual-level data and data that describe relevant framework conditions for entrepreneurship. For example, Start-up Skills captures whether adult individuals think they have the necessary skills to start a new venture, weighted by a measure of the degree of tertiary education in the country. This framework variable is used because the higher a country's level of education, the higher the quality of its entrepreneurial ventures tends to be. Each individual variable is then weighted by a relevant framework condition that regulates a given individual-level variables potential to contribute to a high quality entrepreneurial dynamic. In other words, this approach captures the notion that entrepreneurship ecosystems are brought to life by individual agents, but the ultimate impact of individual-level action is regulated by institutional framework conditions.

The idea of the harmonization of the components of a system goes back to configuration theory (Miller 1986). The interrelation of the system's elements is the core feature of the Theory of the Weakest Link (TWL) and Theory of Constraints (TOC) constructs which argue that the performance of the system depends on the lowest value component in the structure. The TOC proposes that system improvement can only be accomplished if the binding constraint is removed (Goldratt, 1994). The TWL holds that the elements of a system can only be partially substitutable with one another (Yohe and Tol, 2001); this is a feature of our own approach - the Penalty for Bottleneck methodology. The weakest link postulate is also in Lazear who claims that entrepreneurs are rather generalist than specialist; a "jacks-of-alltrades.” (Lazear, 2004). In our framework, as a consequence, success of a business will depend on the entrepreneur's weakest skill. The optimization of the additional resources requires equalizing the marginal effects of the pillars across the system; that is a unique feature of the methodology (see Appendix A).

The methodology captures two other important aspects that define entrepreneurial ecosystems. First, it recognizes that the different pillars need to work together to create a high quality ecosystem dynamic. Traditional indexes fail to capture this aspect. In traditional 
indexing methods, the different components (pillars) are allowed to substitute for one another. If one or more pillars perform poorly, it is likely to hold back the performance of the entire system. Second, the notion of bottlenecks derives directly from the notion that ecosystem elements interact to co-produce ecosystem performance. Because one cannot fully substitute individual pillars for others, poorly performing pillars can create bottlenecks that prevent the ecosystem from fully leveraging its strengths. To simulate this effect the index methodology applies a 'penalty for bottleneck' algorithm. This algorithm systematically penalizes ecosystem pillars according to its poorly performing pillars. These methodological innovations of the index provide important insights into the workings of entrepreneurship ecosystems.

The scores for all the countries are calculated according to the following methodology. ${ }^{5}$

1 The selection of variables: We start with the variables that come directly from the original sources for each country involved in the analysis. These variables can be at the individual level (personal or business) derived from the Global Entrepreneurship Monitor (GEM), Adult Population Survey or the institutional/environmental level from various other as shown in the Appendix. Individual variables for a particular year are calculated as the two year moving average ${ }^{6}$. Institutional variables reflect the most recent available data in that particular year. Altogether we employ 16 individual and 15 institutional variables (for details see Acs et al., 2014).

2 The construction of the pillars: We calculate pillars by multiplying the individual variable with the appropriate institutional variable.

$z_{i, j}=\operatorname{ind}_{i, j} x$ ins $_{i, j}$

for all $\mathrm{j}=1 \ldots \mathrm{k}$, the number of pillars, individual and institutional variables where $z_{i, j}$ is the original pillar value for country $\mathrm{i}$ and pillar $\mathrm{j}$ ind $_{i, j}$ is the original score for country $\mathrm{i}$ and individual variable $\mathrm{j}$ $i n s_{i, j}$ is the original score for country $\mathrm{i}$ and institutional variable $\mathrm{j}$

\footnotetext{
${ }^{5}$ These index building points mainly follow the OECD methodology guide (OECD Handbook 2008). ${ }^{6}$ Provided a country has two consecutive years' individual data. Single year data are used if a country participated in the survey only in a particular year.
} 
3 Normalization: pillars values were first normalized to a range from 0 to 1 according to equation 4:

$x_{i, j}=\frac{z_{i, j}}{\max z_{i, j}}$

for all $\mathrm{j}=1 \ldots \mathrm{k}$, the number of pillars

where $x_{i, j}$ is the normalized score value for country i and pillar $\mathrm{j}$

$z_{i, j}$ is the original pillar value for country $\mathrm{i}$ and pillar $\mathrm{j}$

$\max z_{i, j}$ is the maximum value for pillar $\mathrm{j}$

4 Capping: All index building is based on a benchmarking principle. We selected the 95 percentile score adjustment meaning that any observed values higher than the 95 percentile is lowered to the 95 percentile. The benchmarking calculation is based on the data set containing 77 countries and 234 data points for the 2006-2010 time period.

5 Average pillar adjustment: The different averages of the normalized values of the indicators imply that reaching a given value require different effort and resources. The additional resources for the same marginal improvement of the indicator values should be the same for all indicators. Therefore, we need a transformation to equate the average values of the components. Equation 5 shows the calculation of the average value of pillar $j$ :

$\bar{x}_{j}=\frac{\sum_{i=1}^{n} x_{i, j}}{n}$.

We want to transform the $x_{i, j}$ values such that the potential minimum value is 0 and the maximum value is 1 :

$y_{i, j}=x_{i, j}^{k}$ 
where $k$ is the "strength of adjustment", the $k$-th moment of ${ }^{X_{j}}$ is exactly the needed average, $\bar{y}_{j}$. We have to find the root of the following equation for $k$

$\sum_{i=1}^{n} x_{i, j}^{k}-n \bar{y}_{j}=0$

It is easy to see based on previous conditions and derivatives that the function is decreasing and convex which means it can be quickly solved using the Newton-Raphson method with an initial guess of 0 . After obtaining $k$, the computations are straightforward. Note that if

$$
\begin{array}{ll}
\bar{x}_{j}<\bar{y}_{j} & k<1 \\
\bar{x}_{j}=\bar{y}_{j} & k=1 \\
\bar{x}_{j}>\bar{y}_{j} & k>1
\end{array}
$$

that is $k$ be thought of as the strength (and direction) of adjustment.

The adjusted pillar values are calculated for the 2006-2010 time period. The frequency distributions for the average pillar adjustments are shown in Appendix A with means, standard deviations and the number of observations.

6 Penalizing: After these transformations, the penalty for bottleneck methodology was used to create indicator-adjusted values. The Marginal Rate of compensation means that a loss in one pillar can be compensated by the same increase in another pillar. However, this is not realistic because of the law diminishing returns. Therefore the penalty should rise at an increasing rate. Modifying Casado, Tarabusi and Palazzi's (2012) original function for our purposes we define the penalty function as:

$h_{(i), j}=\min y_{(i), j}+\mathrm{a}\left(1-e^{-\mathrm{b}\left(y_{(i) j}-\min y_{(i), j}\right)}\right)$

where $h_{i, j}$ is the modified, post-penalty value of pillar $\mathrm{j}$ in country $\mathrm{i}$

$y_{i, j}$ is the normalized value of index component $\mathrm{j}$ in country $\mathrm{i}$

$y_{\min }$ is the lowest value of $y_{i, j}$ for country $\mathrm{i}$.

$\mathrm{i}=1,2, \ldots \ldots \mathrm{n}=$ the number of countries

$\mathrm{j}=1,2, \ldots \ldots \mathrm{m}=$ the number of pillars

$0 \leq \mathrm{a}, \mathrm{b} \leq 1$ are the penalty parameters; the basic setup is $\mathrm{a}=\mathrm{b}=1$ 
The PFB pillars improved the correlation, implying a closer relationship between the entrepreneurial features. The positive connection between the pillars is vital for proper policy interpretations and suggestions. If the connection between the pillars were negative, it would imply that one pillar can only be improved at the cost of the other pillars.

7 The pillars are the basic building blocks of the three sub-indices: entrepreneurial attitudes, entrepreneurial abilities, and entrepreneurial aspirations. The value of a subindex for any country is the arithmetic average of its PFB-adjusted pillars for that subindex multiplied by a 100 . The maximum value of the sub-indices is 100 and the potential minimum is 0 , both of which reflect the relative position of a country in a particular sub-index.

$$
\begin{aligned}
& A T T_{i}=100 \sum_{j=1}^{5} h_{j} \\
& A B T_{i}=100 \sum_{j=6}^{9} h_{j} \\
& A S P_{i}=100 \sum_{j=10}^{14} h_{j}
\end{aligned}
$$

where $h_{i, j}$ is the modified, post-penalty value of pillar $\mathrm{j}$ in country $\mathrm{i}$

$\mathrm{i}=1,2, \ldots \ldots \mathrm{n}=$ the number of countries

$\mathrm{j}=1,2, \ldots \ldots .14=$ the number of pillars

8. The super-index is simply the average of the three sub-indices. Since 100 represents the theoretically available limit the GEDI points can also be interpreted as a measure of efficiency of the entrepreneurship resources in a particular institutional setting:

$G E D I_{i}=\frac{1}{3}\left(A T T_{i}+A B T_{i}+A S P_{i}\right)$

where $\mathrm{i}=1,2, \ldots \ldots \mathrm{n}=$ the number of countries

We suggest that this dynamic index construction is particularly useful for evaluating the economic ecosystem in a particular country, and therefore to be fitted into an aggregate production function to capture simultaneously entrepreneurial effort and its efficiency. 
Although one could argue that entrepreneurship is a horizontal policy concept with relevance across a number of traditional policy domains (e.g., trade policy, regulatory policy, fiscal policy), the application of the dynamic index would enable the measurement of the effectiveness of different policy steps toward entrepreneurship. This method could rearrange the ranking of the countries for a particular feature. This approach captures the essential features of the NBL approach to economic growth including factors that are not proximate causes of growth.

\section{Data and Results}

In this paper, we propose the concept of the national entrepreneurial ecosystem and attempt to measure its impact on economic growth. The measure is complex as it assumes interdependence between many individual dimensions that capture both institutions and entrepreneurship. It is therefore a data intensive exercise. Yet until 1998, which is when the Global Entrepreneurship Monitor (GEM) data were first collected for ten countries, there were no cross-country comparative measure of entrepreneurial activity that could be utilised for a study of this type. Likewise, it is only recently that multiple efforts to operationalise and measure the institutional dimensions emerged. Taken together, these facts imply that we still face very serious data constraints that in turn limit both the range of feasible estimators and the power of econometric tests we can apply to investigate correlations between our proposed empirical measure of national entrepreneurial ecosystem and economic growth.

In testing the latter relationship we rely on the aggregate production function approach. The standard factors of production (capital and labour) are augmented with our variables of interest. The limiting factor is availability of longitudinal data on entrepreneurship as provided by GEM, and with a relatively small dataset, it is difficult to implement more ambitious functional forms.

\subsection{Data and descriptive statistics}

The data on real GDP growth, fixed capital investment and labour derive from the Penn World Table (PWT version 8). The PWT project originates with the Center for International Comparisons of Production, Income and Prices at the University of Pennsylvania (Heston et al., 2012) and is now run jointly by the team at the University of California at Davis and University of Groningen (Feenstra et al., 2013). The project team also secured assistance and cooperation from the statistical offices of the World Bank, OECD and EU. The unique feature of the latest version of the PENN table is availability of capital stock and investment data. PENN data is considered of top quality and has been used widely for empirical work on economic growth.

The growth data we use in our estimations are summarized in table below. 
Table 2. Growth data used in estimations

\begin{tabular}{|c|c|c|c|c|c|}
\hline Country & Obs & Mean & Std. Dev. & Min & Max \\
\hline Argentina & 9 & 0.07 & 0.03 & 0.01 & 0.09 \\
\hline Australia & 5 & 0.03 & 0.00 & 0.03 & 0.04 \\
\hline Belgium & 9 & 0.02 & 0.02 & -0.03 & 0.03 \\
\hline Bosnia & 3 & 0.00 & 0.02 & -0.03 & 0.02 \\
\hline Brazil & 9 & 0.04 & 0.02 & 0.00 & 0.07 \\
\hline Canada & 4 & 0.03 & 0.01 & 0.02 & 0.03 \\
\hline Chile & 7 & 0.04 & 0.02 & -0.01 & 0.06 \\
\hline China & 5 & 0.11 & 0.02 & 0.09 & 0.13 \\
\hline Colombia & 5 & 0.04 & 0.02 & 0.02 & 0.07 \\
\hline Croatia & 9 & 0.02 & 0.04 & -0.07 & 0.05 \\
\hline Denmark & 9 & 0.01 & 0.03 & -0.06 & 0.03 \\
\hline Dominican $\mathrm{R}$ & 2 & 0.04 & 0.01 & 0.03 & 0.05 \\
\hline Ecuador & 2 & 0.02 & 0.02 & 0.00 & 0.04 \\
\hline Finland & 9 & 0.02 & 0.04 & -0.09 & 0.05 \\
\hline France & 9 & 0.01 & 0.02 & -0.03 & 0.03 \\
\hline Germany & 7 & 0.01 & 0.03 & -0.05 & 0.04 \\
\hline Greece & 8 & 0.00 & 0.04 & -0.07 & 0.05 \\
\hline Guatemala & 2 & 0.03 & 0.01 & 0.03 & 0.04 \\
\hline Hong Kong & 2 & 0.06 & 0.04 & 0.03 & 0.08 \\
\hline Hungary & 7 & 0.01 & 0.04 & -0.07 & 0.04 \\
\hline Iceland & 8 & 0.02 & 0.05 & -0.07 & 0.08 \\
\hline India & 2 & 0.07 & 0.04 & 0.04 & 0.09 \\
\hline Iran & 3 & 0.04 & 0.02 & 0.02 & 0.06 \\
\hline Ireland & 7 & 0.03 & 0.03 & -0.02 & 0.06 \\
\hline Israel & 3 & 0.03 & 0.02 & 0.01 & 0.05 \\
\hline Italy & 8 & 0.00 & 0.03 & -0.06 & 0.02 \\
\hline Jamaica & 4 & 0.00 & 0.03 & -0.03 & 0.03 \\
\hline Japan & 9 & 0.01 & 0.03 & -0.06 & 0.04 \\
\hline Latvia & 6 & 0.00 & 0.11 & -0.20 & 0.11 \\
\hline Malaysia & 2 & 0.06 & 0.01 & 0.05 & 0.07 \\
\hline Mexico & 2 & 0.04 & 0.01 & 0.04 & 0.05 \\
\hline Netherlands & 9 & 0.01 & 0.02 & -0.04 & 0.04 \\
\hline Norway & 9 & 0.01 & 0.02 & -0.02 & 0.04 \\
\hline Pakistan & 1 & 0.03 & . & 0.03 & 0.03 \\
\hline Peru & 5 & 0.07 & 0.03 & 0.01 & 0.09 \\
\hline Portugal & 1 & -0.02 & . & -0.02 & -0.02 \\
\hline Romania & 4 & 0.00 & 0.06 & -0.07 & 0.07 \\
\hline Russia & 5 & 0.03 & 0.06 & -0.08 & 0.08 \\
\hline Saudi Arabia & 1 & 0.05 & . & 0.05 & 0.05 \\
\hline Serbia & 2 & 0.00 & 0.05 & -0.04 & 0.04 \\
\hline Singapore & 4 & 0.07 & 0.02 & 0.04 & 0.09 \\
\hline Slovenia & 9 & 0.02 & 0.04 & -0.08 & 0.07 \\
\hline South Africa & 7 & 0.03 & 0.02 & -0.02 & 0.05 \\
\hline South Korea & 3 & 0.03 & 0.03 & 0.00 & 0.06 \\
\hline Spain & 9 & 0.02 & 0.03 & -0.04 & 0.04 \\
\hline Sweden & 6 & 0.03 & 0.01 & 0.02 & 0.04 \\
\hline Switzerland & 3 & 0.02 & 0.02 & 0.00 & 0.03 \\
\hline Taiwan & 1 & 0.04 & . & 0.04 & 0.04 \\
\hline Thailand & 2 & 0.05 & 0.00 & 0.05 & 0.05 \\
\hline Trinidad & 1 & -0.01 & . & -0.01 & -0.01 \\
\hline Tunisia & 1 & 0.03 & . & 0.03 & 0.03 \\
\hline Turkey & 3 & 0.04 & 0.04 & 0.01 & 0.08 \\
\hline Uganda & 2 & 0.06 & 0.00 & 0.06 & 0.06 \\
\hline UK & 9 & 0.01 & 0.03 & -0.04 & 0.04 \\
\hline United States & 9 & 0.02 & 0.02 & -0.03 & 0.03 \\
\hline Uruguay & 5 & 0.06 & 0.02 & 0.02 & 0.09 \\
\hline
\end{tabular}


The construction of GEDI index was described above, and for our robustness checks we utilise the human capital index, now also incorporated into the PENN tables. This is important as we wish to contrast our results with those based on a measure anchored in earlier versions of growth theory as discussed above. The human capital index (per person) is based on two dimensions: years of schooling (Barro and Lee, 2013) and returns to education (Psacharopoulos, 1994). Note that we are only able to use a subset of the countries available in the PENN tables for the test of the effect of the entrepreneurial ecosystem because of the limited availability of GEDI data.

A correlation table follows next. Our sample for the table is drawn on the 2003-2011 period that is available for all indicators.

\section{Table 3. Variables definitions and descriptive statistics}

\begin{tabular}{|l|l|l|l|}
\hline Name & Description & Mean & St. Dev. \\
\hline d_ln_rgdpana & $\begin{array}{l}\text { Logarithmic change (year to year) in real } \\
\text { GDP at constant 2005 national prices in mil. } \\
\text { 2005 US\$ (from PENN World Table v.8). } \\
\text { Dependent variable }\end{array}$ & 0.026 & 0.038 \\
\hline d_ln_emp & $\begin{array}{l}\text { Logarithmic change (year to year) in number } \\
\text { of persons engaged (in millions) (from PENN } \\
\text { World Table v.8) }\end{array}$ & 0.011 & 0.025 \\
\hline d_ln_rkna & $\begin{array}{l}\text { Logarithmic change (year to year) in capital } \\
\text { stock at constant 2005 national prices (in mil. } \\
\text { 2005 US\$) (from PENN World Table v.8) }\end{array}$ & 0.035 & 0.023 \\
\hline d_GEDI & $\begin{array}{l}\text { Change in GEDI index, system version with } \\
\text { penalties for bottlenecks, year to year (source: } \\
\text { authors' calculation) }\end{array}$ & 0.724 & 3.798 \\
\hline d_hc & $\begin{array}{l}\text { Change in index of human capital per person, } \\
\text { based on years of schooling (Barro/Lee, } \\
\text { 2012) and returns to education } \\
\text { (Psacharopoulos, 1994) (from PENN World } \\
\text { Table v.8) }\end{array}$ & 0.014 & 0.013 \\
\hline
\end{tabular}


Table 4. Correlation matrix
D. In_rgdpana
D. In_emp
D. In_rkna
D.gedi D.hc

D.In_rgdpana | 1.0000
D. In_emp |
0.6224
1.0000
D.In_rkna |
0.5285
0.3835
1.0000
D.gedi I
0.1228
0.1117
0.0760
1.0000
D.he ।
0.0773
0.0893
$\odot .1502$
0.0230
1.0000

We also present the results of the simple correlation between change in Gedi and rate of growth ( $\mathrm{R}$ squared at $12.3 \%$ as in the table above) in a form of a graph. This simple correlation is significant at $5 \%$ level.

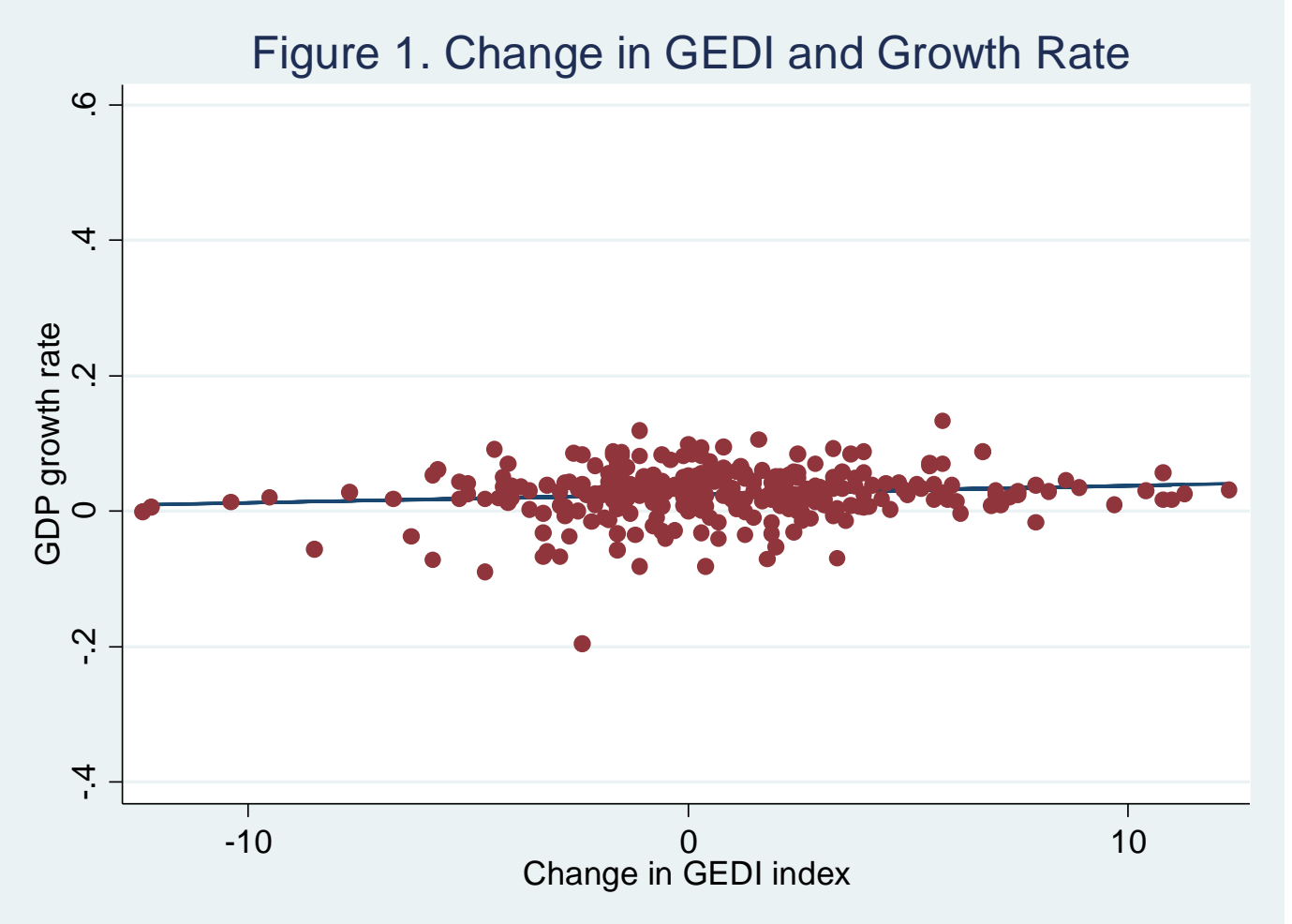

\subsection{Methods of estimation}

The data comes with gaps which makes the application of demanding estimation techniques, which rely on instrumenting, hard to implement. In particular, successfully applying dynamic panel data models based on generalised methods of moments proved to be impossible, due to the fact that we do not have a sufficient number of longer sequences of data for countries in our sample. For that reason we fall back on robust, even if less efficient, fixed effects 
estimator. At the same time, to enhance robustness, we apply one additional measure: we take our variables in first differences - therefore, we have economic growth regressed on employment, fixed capital, the measure of the national entrepreneurial ecosystem and human capital dynamics. The specification we use follows a design where a simple production function is gradually augmented by other elements, as for example in Estrin et al. (2007).

Consistent with that we first estimate a model which only includes our measures of capital and labour (eq. 1 in Table 3). Next, we introduce the full system version of the GEDI index. Finally in equation 3, we also include the human capital index, so we have it jointly with the GEDI index and PENN-based measures of labour and capital. When we include only measures of the human capital index, it is not significant and so the results are not reported.

Results of all these estimations are presented in table below.

\section{Table 5: Estimates of economic growth model}

\section{DEPENDENT VARIABLE: GDP GROWTH RATE}
(1)
(2)
(3)

\section{VARIABLES}
Capital
$0.563 * * *$
$0.622 * *$
$0.640 * *$
(0.119)
(0.225)
(0.232)
Employment
$0.252 * * *$
$0.746^{* * *}$
$0.736^{* * *}$
(0.0701)
(0.110)

Human capital index

0.0120

(0.139)

GEDI: system version

$0.000512+\quad 0.000510+$

(0.000288) (0.000287)

Constant

$0.0138 * *$

$-0.00434 \quad-0.00486$

(0.00490)

$(0.00708) \quad(0.00751)$

Observations

1,796

287

284

R-squared

0.111

0.444

0.443

Number of countries

165

56

55

Notes : Fixed effects estimator. Robust standard errors in parentheses. All explanatory variables as rates of growth (approximated by logarithmic differences)

$* * * \mathrm{p}<0.001,{ }^{* *} \mathrm{p}<0.01,{ }^{*} \mathrm{p}<0.05,+\mathrm{p}<0.10$ 


\subsection{Results}

Equation (1) estimates a basic production function using the entire Penn table dataset. The effect of investment comes as positive and highly significant. The same applies to the effect of labor. Both coefficients are in a plausible range. The effect of investment is stronger, but comparing these two, one needs to keep in mind Solow's argument which is that investment often has technological change embedded in it. It is worth reiterating that the production function performs well despite the fact that the models we apply are demanding (first differencing, use of fixed effects). In equation (2) we include a full, system version of GEDI though to the more limited dataset. The production function continues to perform well despite the decline in country coverage. The GEDI index is weakly significant. One may also note that for the model with GEDI, the relative strength of labour and capital effects changes: now, the effect of labour becomes stronger compared with the effect of capital. It is as if the GEDI measure that combines influence of the institutional setup and entrepreneurship absorbed some of the effect that the capital variable was capturing before; the latter due to an omitted variable bias. In the final equation we add the human capital index so we have it jointly with GEDI in the same equation. The amount of explained variance does not increase and GEDI index remains significant and the human capital index is insignificant. Thus GEDI seems to capture much of the effect that has previously been interpreted as deriving from human capital.

We get a flavour of the strength of the effects by calculating linear predictions for different values of change in the GEDI index. The predicted rate of GDI growth, at mean value of change in GEDI of 0.7 , is $2.6 \%$. One standard deviation above the mean change in GEDI (at $4.5 \%$ ) we get predicted GDP growth at $2.8 \%$. For a change in GEDI one standard deviation below the mean (at $-3.1 \%$ ) we get GDP growth at $2.4 \%$. This annual effect does not seem large, but obviously it has much more significant impact if the positive change in the ecosystem continuous over a period of several years. In our data, an example of a positive change in GEDI that continued over a period of several years in 2000s is Croatia; an example where negative changes in GEDI dominated over positive ones is Argentina.

\section{Conclusions}

In this paper we argue that while the formal institutions conducive to generating wealth create necessary conditions for economic development, these are not sufficient conditions. It is only when the opportunities generated by strong institutional frameworks are realised by entrepreneurs through an ecosystem that economic growth follows. Entrepreneurs commercialize innovations and therefore represent the mechanism transferring advances in knowledge into growth. The stronger the institutions, the more productive will be entrepreneurship and the greater the impact of entrepreneurs on growth. We therefore propose that the combination of agency and institutions represent the "missing link" in knowledge based models of economic growth. 
We have therefore argued that individual agency and the institutional context have to be considered jointly and proposed that this can be done by identifying the role of the national entrepreneurial ecosystem in economic growth. It is the interaction of private initiative and adequate institutional frameworks shaped by collective choice that deliver economic growth and this is what is captured by the concept of the entrepreneurial ecosystem. To test the role of the entrepreneurial ecosystem, we drew on the operationalization of this idea by Acs et al. (2014) in the form of GEDI index. It is important that we find the system version of GEDI correlates with growth; one that operationalizes the concepts of bottlenecks and claims these have particularly negative effects on development. The policy message is that a weak performance on a particular feature, such as a bottleneck, should be handled first because it has the most negative effect, dampening impact of all the other features.

Our contribution is primarily conceptual as our empirical counterpart is seriously constrained by data availability, yet in the latter we have shown that a measure of the national entrepreneurial ecosystem does have a (weakly) significant impact on cross country growth pattern over time, even if the number of countries under consideration is relatively small and the estimation methods employed are demanding. Moreover, our results indicate that GEDI enables us to increase the share of explained variance in total variance significantly, and the results hold when controlling for an alternative explanation taken from the literature on determinants of economic growth that is human capital.

In this paper we have been inspired by the comparison between the Soviet Union and the United States to explain the source of the Solow residual. All explanations of the Solow Residual so far have focused on stocks of Capital, Labor, Human Capital and Knowledge and all of them have explained less than $50 \%$ of the residual. We instead propose that the systems approach which combines individual agency with institutions might be a more fruitful place to look for the explanation. 
References

Acemoglu, D., and Johnson, S. (2005). Unbundling institutions. Journal of Political Economy, 113(5), 949-995.

Acemoglu, D., Johnson, S., and Robinson, J. A. (2005). Institutions as a fundamental cause of long-run growth. In Aghion, P., and Durlauf, S. N. (Eds.). (2005). Handbook of economic growth, Amsterdam: Elsvier, 1, 385-472.

Acs, Z. J., Autio, E., and Szerb, L. (2014). National systems of entrepreneurship:

Measurement issues and policy implications. Research Policy, 43(3), 476-494.

Acs, Z. J. and Sanders, M. (2013). Knowledge spillover entrepreneurship in an endogenous growth model, Small Business Economics, 41(4), 775-796.

Arrow, K. J. (1962). "Economic Welfare and the Allocation of Resources for Invention," in R. R. Nelson (ed.) The Rate and Direction of Inventive Activity. Princeton: Princeton University Press, 609-626.

Abdih, Y and Joutz, F., (2006). Relating the knowledge production function to total factor productivity: An endogenous growth puzzle, IMF Staff Papers, 53(2), 242-271.

Aghion P., and Howitt, P.A. (1992). Model of growth through creative destruction Econometrica, Vol. 60(2), 323-351

Aidis, R., Estrin, S., Mickiewicz, T. (2008). Institutions and entrepreneurship development in Russia: a comparative perspective. Journal of Business Venturing, 23, 656-672.

Barro, R.J., (199l). Economic growth in a cross section of countries, Quarterly Journal of Economics CVI, May, 407-444.

Barro, R.J. and X. Sala-i-Martin, (1995). Economic Growth McGraw Hill, Boston, MA).

Baumol, W. (1990). Entrepreneurship: Productive, unproductive and destructive. Journal of Political Economy, 98(5), 893-921.

Baumol, W. J. (1993). Formal entrepreneurship theory in economics: existence and bounds. Journal of Business Venturing 8 (3), 197-210.

Baumol, W. J. Strom, R. J. (2007). Entrepreneurship and economic growth. Strategic Entrepreneurship Journal, 1 (3-4), 233-237.

Braunerhjelm, P., Acs, Z. J. Audretsch, D. B. and Carlsson, B. (2010). The missing link: Knowledge diffusion and entrepreneurship in endogenous growth, Small Business Economics, 43(1), 105-125.

Casadio Tarabusi, E., and Palazzi, P. (2012). An index for sustainable development. PSL Quarterly Review, 57(229). 
Carree, M.A., Thurik, R. (2003). The Impact of Entrepreneurship on Economic Growth in Audretsch D., and Acs, Z., The Handbook of Entrepreneurship Research, Boston: Kluwer, 425-486.

Desai, S., Acs, Z. J. and Weitzel, U. (2013). A theory of destructive entrepreneurship: Insights on conflict, post conflict recovery, Journal of Conflict Resolution, 57(1), 20-40.

Dreher, A, N. Gaston and P. Martens (2008), Measuring Globalisation - Gauging its Consequences New York: Springer.

Furerlinger, G., Funke, T. and Fandl, U. (2014). The role of the state in the entrepreneurial ecosystem: Insights from Germany, Austrian Institute of Technology, Vienna, Austria.

Goldratt, E. M. (1994). The goal: A process of ongoing improvement, 2nd ed. Great Barrington, MA: North River Press.

Groh, A, H. Liechtenstein and Lieser, K. (2012). The Global Venture Capital and Private Equity Country Attractiveness Index 2012 Annual, http://blog.iese.edu/vcpeindex/about/

Jones, C. I. and Romer, P. M. (2009). The new Kaldor facts: Ideas, intuitions, population and human capital, NBER Working Paper Series, Working Paper 15094, Cambridge, MA.

Lazear E. P. (2004). Balanced skills and entrepreneurship. The American Economic Review, 94(2), 208-211.

North, D. C. (1990). Institutions. Institutional change and economic performance, Cambridge: Cambridge University Press.

Michelacci, C. (2003). Low returns to R\&D due to the lack of entrepreneurial skills, The Economic Journal, 113, 207-225.

Miller, D. (1986). Configurations of strategy and structure: Towards a synthesis. Strategic Management Journal, 7, 233-249.

Murphy, K. M., Shleifer, A. and Vishny, R. W. (1993). Why is rent-seeking so costly to growth? American Economic Review. Papers and Proceedings, 83, 409-414.

OECD Handbook (2008). Organization for Economic Co-operation Development. Handbook of constructing composite indicators: Methodology and user guide 2008: OECD Publishing. Paris

Ofer, G, (1987). Soviet economic growth, 1928-85, Journal of Economic Literature, 25(4), 1676-1853.

Parker, S. C. (2009). The economics of entrepreneurship. Cambridge: Cambridge University Press.

Romer, P. (1986). Increasing returns and long run growth, Journal of Political Economy 99, June, 500-521. 
Romer, P. (1990). Endogenous technological change, Journal of Political Economy 98, Oct., 71-102.

Schumpeter, J. [2008 (1934)]. The Theory of Economic Development. New Brunswick, N.J.: Transaction Publishers.

Solow, R.M. (1956). A contribution to the theory of economic growth, Quarterly Journal Of Economics, 70, 65-94.

Solow, R.M. (1957) Technical Change and the Aggregate Production Function, Review of Economics and Statistics, 39(3), 312-20.

Van Praag, C. M., Versloot, P.H. (2007). What is the value of entrepreneurship? A review of recent research, Small Business Economics, 29(4), 351-82.

Yohe, G., and R. S. J. Tol. (2001). Indicators for social and economic coping capacity: Moving toward a working definition of adaptive capacity. Global Environmental Change, 12, 25-40. 
Appendix A

The description of the individual variables used in the GEDI

\begin{tabular}{|c|c|}
\hline $\begin{array}{l}\text { Individual } \\
\text { variable }\end{array}$ & Description \\
\hline $\begin{array}{l}\text { Opportunity } \\
\text { Recognition }\end{array}$ & $\begin{array}{l}\text { The percentage of the 18-64 aged population recognizing good conditions to } \\
\text { start business next } 6 \text { months in area he/she lives, }\end{array}$ \\
\hline $\begin{array}{l}\text { Skill } \\
\text { Perception }\end{array}$ & $\begin{array}{l}\text { The percentage of the 18-64 aged population claiming to possess the } \\
\text { required knowledge/skills to start business }\end{array}$ \\
\hline $\begin{array}{l}\text { Risk } \\
\text { Acceptance }\end{array}$ & $\begin{array}{l}\text { The percentage of the 18-64 aged population stating that the fear of failure } \\
\text { would not prevent starting a business }\end{array}$ \\
\hline $\begin{array}{l}\text { Know } \\
\text { Entrepreneurs }\end{array}$ & $\begin{array}{l}\text { The percentage of the } 18-64 \text { aged population knowing someone who started } \\
\text { a business in the past } 2 \text { years }\end{array}$ \\
\hline Carrier & $\begin{array}{l}\text { The percentage of the 18-64 aged population saying that people consider } \\
\text { starting business as good carrier choice }\end{array}$ \\
\hline Status & $\begin{array}{l}\text { The percentage of the 18-64 aged population thinking that people attach } \\
\text { high status to successful entrepreneurs }\end{array}$ \\
\hline Career Status & $\begin{array}{l}\text { The status and respect of entrepreneurs calculated as the average of Carrier } \\
\text { and Status }\end{array}$ \\
\hline $\begin{array}{l}\text { Opportunity } \\
\text { Motivation }\end{array}$ & $\begin{array}{l}\text { Percentage of the TEA businesses initiated because of opportunity start-up } \\
\text { motive }\end{array}$ \\
\hline $\begin{array}{l}\text { Technology } \\
\text { Level }\end{array}$ & $\begin{array}{l}\text { Percentage of the TEA businesses that are active in technology sectors (high } \\
\text { or medium) }\end{array}$ \\
\hline $\begin{array}{l}\text { Educational } \\
\text { Level }\end{array}$ & $\begin{array}{l}\text { Percentage of the TEA businesses owner/managers having participated over } \\
\text { secondary education }\end{array}$ \\
\hline Competitors & $\begin{array}{l}\text { Percentage of the TEA businesses started in those markets where not many } \\
\text { businesses offer the same product }\end{array}$ \\
\hline New Product & $\begin{array}{l}\text { Percentage of the TEA businesses offering products that are new to at least } \\
\text { some of the customers }\end{array}$ \\
\hline New Tech & $\begin{array}{l}\text { Percentage of the TEA businesses using new technology that is less than } 5 \\
\text { years old average (including } 1 \text { year) }\end{array}$ \\
\hline
\end{tabular}




\begin{tabular}{|l|l|}
\hline Gazelle & $\begin{array}{l}\text { Percentage of the TEA businesses having high job expectation average (over } \\
10 \text { more employees and } 50 \% \text { in } 5 \text { years) }\end{array}$ \\
\hline Export & $\begin{array}{l}\text { Percentage of the TEA businesses where at least some customers are outside } \\
\text { country (over 1\%) }\end{array}$ \\
\hline $\begin{array}{l}\text { Informal } \\
\text { Investment } \\
\text { Mean }\end{array}$ & The mean amount of 3 year informal investment \\
\hline $\begin{array}{l}\text { Business } \\
\text { Angel }\end{array}$ & $\begin{array}{l}\text { The percentage of the 18-64 aged population who provided funds for new } \\
\text { business in past } 3 \text { years excluding stocks \& funds, average }\end{array}$ \\
\hline $\begin{array}{l}\text { Informal } \\
\text { Investment }\end{array}$ & $\begin{array}{l}\text { The amount of informal investment calculated as INFINVMEAN* } \\
\text { BUSANG }\end{array}$ \\
\hline
\end{tabular}


The description and source of the institutional variables used in the GEDI

\begin{tabular}{|c|c|c|c|}
\hline $\begin{array}{l}\text { Institutional } \\
\text { Variable }\end{array}$ & Description & $\begin{array}{l}\text { Source } \\
\text { of Data }\end{array}$ & Data Availability \\
\hline $\begin{array}{l}\text { Domestic } \\
\text { Market }\end{array}$ & $\begin{array}{l}\text { Domestic market size that is the sum of gross domestic product plus value of } \\
\text { imports of goods and services, minus value of exports of goods and services, } \\
\text { normalized on a 1-7 (best) scale data are from the World Economic Forum } \\
\text { Competitiveness }\end{array}$ & $\begin{array}{l}\text { World } \\
\text { Economic } \\
\text { Forum }\end{array}$ & $\begin{array}{l}\text { The Global } \\
\text { Competitiveness } \\
\text { Report 2005-2006, } \\
\text { 2006-2007, 2007-2008, } \\
\text { 2008-2009, 2009-2010, }\end{array}$ \\
\hline Urbanization & $\begin{array}{l}\text { Urbanization that is the percentage of the population living in urban areas, } \\
\text { data are from the Population Division of the United Nations, } 2011\end{array}$ & $\begin{array}{l}\text { United } \\
\text { Nations }\end{array}$ & $\begin{array}{l}\text { http://data.worldbank.o } \\
\text { rg/indicator/SP.URB.T } \\
\text { OTL.IN.ZS/countries }\end{array}$ \\
\hline $\begin{array}{l}\text { Market } \\
\text { Agglomerati } \\
\text { on }\end{array}$ & $\begin{array}{l}\text { The size of the market: a combined measure of the domestic market size and } \\
\text { the urbanization that later measures the potential agglomeration effect. } \\
\text { Calculated as domestic market urbanization* }\end{array}$ & $\begin{array}{l}\text { Own } \\
\text { calculation }\end{array}$ & - \\
\hline $\begin{array}{l}\text { Tertiary } \\
\text { Education }\end{array}$ & Gross enrolment ratio in tertiary education, 2011 or latest available data. & UNESCO & $\begin{array}{l}\text { http://stats.uis.unesco.org/un } \\
\text { esco/TableViewer/tableVie } \\
\text { w.aspx?ReportId=167 }\end{array}$ \\
\hline $\begin{array}{l}\text { Business } \\
\text { Risk }\end{array}$ & $\begin{array}{l}\text { The business climate rate "assesses the overall business environment quality } \\
\text { in a country...It reflects whether corporate financial information is available } \\
\text { and reliable, whether the legal system provides fair and efficient creditor }\end{array}$ & Coface & http://www.coface.com \\
\hline
\end{tabular}




\begin{tabular}{|c|c|c|c|}
\hline & $\begin{array}{l}\text { protection, and whether a country's institutional framework is favorable to } \\
\text { intercompany transactions” (http://www.trading-safely.com/). It is a part of } \\
\text { the country risk rate. The alphabetical rating is turned to a seven-point Likert } \\
\text { scale from } 1 \text { (D rating) to } 7 \text { (A1 rating). December 30, } 2012 \text { data }\end{array}$ & & $\begin{array}{l}\text { /CofacePortal/COM_en } \\
\text { _EN/pages/home/risks_ } \\
\text { home/business_climate } \\
\text { /rating_table?geoarea- } \\
\text { country=\&crating=\&br } \\
\text { ating= }\end{array}$ \\
\hline $\begin{array}{l}\text { Internet } \\
\text { Usage }\end{array}$ & $\begin{array}{l}\text { The number of Internet users in a particular country per } 100 \text { inhabitants, } 2012 \\
\text { data }\end{array}$ & $\begin{array}{l}\text { International } \\
\text { Telecommun } \\
\text { ication } \\
\text { Union }\end{array}$ & $\begin{array}{l}\text { http://www.itu.int/en/I } \\
\text { TU- } \\
\text { D/Statistics/Pages/stat/ } \\
\text { default.aspx }\end{array}$ \\
\hline Corruption & $\begin{array}{l}\text { The Corruption Perceptions Index (CPI) measures the perceived level of } \\
\text { public-sector corruption in a country. “The CPI is a 'survey of surveys', based } \\
\text { on } 13 \text { different expert and business surveys.” } \\
\text { (http://www.transparency.org/policy_research/surveys_indices/cpi/2009 ) } \\
\text { Overall performance is measured on a ten-point Likert scale. Data are from } \\
2012 .\end{array}$ & $\begin{array}{l}\text { Transparenc } \\
\mathrm{y} \\
\text { International }\end{array}$ & $\begin{array}{l}\text { http://cpi.transparency. } \\
\text { org/ }\end{array}$ \\
\hline $\begin{array}{l}\text { Economic } \\
\text { Freedom }\end{array}$ & $\begin{array}{l}\text { "Business freedom is a quantitative measure of the ability to start, operate, } \\
\text { and close a business that represents the overall burden of regulation, as well as } \\
\text { the efficiency of government in the regulatory process. The business freedom } \\
\text { score for each country is a number between } 0 \text { and 100, with } 100 \text { equaling the } \\
\text { freest business environment. The score is based on } 10 \text { factors, all weighted } \\
\text { equally, using data from the World Bank’s Doing Business study.” } \\
\text { (http://www.heritage.org/Index/pdf/Index09_Methodology.pdf). Data are from } 2011 .\end{array}$ & $\begin{array}{l}\text { Heritage } \\
\text { Foundation/ } \\
\text { World Bank }\end{array}$ & $\begin{array}{l}\text { http://www.heritage.or } \\
\text { g/index/explore.aspx }\end{array}$ \\
\hline $\begin{array}{l}\text { Tech } \\
\text { Absorption }\end{array}$ & $\begin{array}{l}\text { Firm-level technology absorption capability: “Companies in your country are } \\
(1=\text { not able to absorb new technology, } 7 \text { = aggressive in absorbing new }\end{array}$ & $\begin{array}{l}\text { World } \\
\text { Economic }\end{array}$ & $\begin{array}{l}\text { The Global } \\
\text { Competitiveness }\end{array}$ \\
\hline
\end{tabular}




\begin{tabular}{|c|c|c|c|}
\hline & technology)” & Forum & $\begin{array}{l}\text { Report 2005-2006, } \\
\text { 2006-2007, 2007-2008, } \\
\text { 2008-2009, 2009-2010, }\end{array}$ \\
\hline $\begin{array}{l}\text { Staff } \\
\text { Training }\end{array}$ & $\begin{array}{l}\text { The extent of staff training: "To what extent do companies in your country } \\
\text { invest in training and employee development? ( } 1=\text { hardly at all; } 7=\text { to a great } \\
\text { extent)" }\end{array}$ & $\begin{array}{l}\text { World } \\
\text { Economic } \\
\text { Forum }\end{array}$ & $\begin{array}{l}\text { The Global } \\
\text { Competitiveness } \\
\text { Report 2005-2006, } \\
\text { 2006-2007, 2007-2008, } \\
\text { 2008-2009, 2009-2010, }\end{array}$ \\
\hline $\begin{array}{l}\text { Market } \\
\text { Dominance }\end{array}$ & $\begin{array}{l}\text { Extent of market dominance: "Corporate activity in your country is (1 = } \\
\text { dominated by a few business groups, } 7 \text { = spread among many firms)" }\end{array}$ & $\begin{array}{l}\text { World } \\
\text { Economic } \\
\text { Forum }\end{array}$ & $\begin{array}{l}\text { The Global } \\
\text { Competitiveness } \\
\text { Report 2005-2006, } \\
\text { 2006-2007, 2007-2008, } \\
\text { 2008-2009, 2009-2010, }\end{array}$ \\
\hline $\begin{array}{l}\text { Technology } \\
\text { Transfer }\end{array}$ & $\begin{array}{l}\text { These are the innovation index points from GCI: a complex measure of } \\
\text { innovation, including investment in research and development (R\&D) by the } \\
\text { private sector, the presence of high-quality scientific research institutions, the } \\
\text { collaboration in research between universities and industry, and the protection } \\
\text { of intellectual property }\end{array}$ & $\begin{array}{l}\text { World } \\
\text { Economic } \\
\text { Forum }\end{array}$ & $\begin{array}{l}\text { The Global } \\
\text { Competitiveness } \\
\text { Report 2005-2006, } \\
\text { 2006-2007, 2007-2008, } \\
\text { 2008-2009, 2009-2010, }\end{array}$ \\
\hline GERD & $\begin{array}{l}\text { Gross domestic expenditure on R\&D (GERD) as a percentage of GDP, year } \\
2011 \text { or latest available data; Puerto Rico, Dominican Republic, United Arab } \\
\text { Emirates, and some African countries are estimated }\end{array}$ & UNESCO & $\begin{array}{l}\underline{\text { http://stats.uis.unesco.org/un }} \\
\underline{\text { esco/TableViewer/tableVie }} \\
\underline{\text { w.aspx?ReportId=2656 }}\end{array}$ \\
\hline $\begin{array}{l}\text { Business } \\
\text { Strategy }\end{array}$ & $\begin{array}{l}\text { Refers to the ability of companies to pursue distinctive strategies, which } \\
\text { involves differentiated positioning and innovative means of production and } \\
\text { service delivery }\end{array}$ & $\begin{array}{l}\text { World } \\
\text { Economic } \\
\text { Forum }\end{array}$ & $\begin{array}{l}\text { The Global } \\
\text { Competitiveness } \\
\text { Report 2005-2006, } \\
\text { 2006-2007, 2007-2008, }\end{array}$ \\
\hline
\end{tabular}




\begin{tabular}{|c|c|c|c|}
\hline & & & 2008-2009, 2009-2010, \\
\hline $\begin{array}{l}\text { Globalizatio } \\
\text { n }\end{array}$ & $\begin{array}{l}\text { A part of the Globalization Index measuring the economic dimension of } \\
\text { globalization. The variable involves the actual flows of trade, foreign direct } \\
\text { investment, portfolio investment, and income payments to foreign nationals, } \\
\text { as well as restrictions of hidden import barriers, mean tariff rate, taxes on } \\
\text { international trade, and capital account restrictions. Data are from the } 2013 \\
\text { report and based on the } 2010 \text { survey. } \\
\text { http://globalization.kof.ethz.ch/media/filer_public/2013/03/25/rankings_2013.pdf }\end{array}$ & $\begin{array}{l}\text { KOF Swiss } \\
\text { Economic } \\
\text { Institute }\end{array}$ & $\begin{array}{l}\text { Dreher, A. (2006). } \\
\text { Does Globalization } \\
\text { Affect Growth? } \\
\text { Evidence from a new } \\
\text { Index of Globalization, } \\
\text { Applied Economics 38, } \\
\text { 10: 1091-1110. }\end{array}$ \\
\hline $\begin{array}{l}\text { Depth of } \\
\text { Capital } \\
\text { Market }\end{array}$ & $\begin{array}{l}\text { The depth of capital market is one of the six sub-indices of the Venture } \\
\text { Capital and Private Equity Index. This variable is a complex measure of the } \\
\text { size and liquidity of the stock market, level of IPO, M\&A, and debt and credit } \\
\text { market activity. Note that there were some methodological changes over the } \\
\text { 2006-2012 time period, so comparison to previous years is not perfect. The } \\
\text { dataset is provided by Alexander Groh.* }\end{array}$ & $\begin{array}{l}\text { EMLYON } \\
\text { Business } \\
\text { School, } \\
\text { France and } \\
\text { IESE } \\
\text { Business } \\
\text { School, } \\
\text { Barcelona, } \\
\text { Spain }\end{array}$ & $\begin{array}{l}\text { Groh, A, H. } \\
\text { Liechtenstein and K. } \\
\text { Lieser. (2012). The } \\
\text { Global Venture Capital } \\
\text { and Private Equity } \\
\text { Country Attractiveness } \\
\text { Index } 2012 \text { Annual, } \\
\text { http://blog.iese.edu/vcpeind } \\
\text { ex/about/ }\end{array}$ \\
\hline
\end{tabular}

Per capita GDP

The per capita GDP is basically in 2005 constant international \$ as reported by the World Bank, http://www.quandl.com/browse/worldbank/world-development-indicators/economic-policy-external-debt/gdp-per-capita-ppp-constant-2005international-all-countries, Downloaded: 06/10/2014 
GEDI Components: Distribution tables
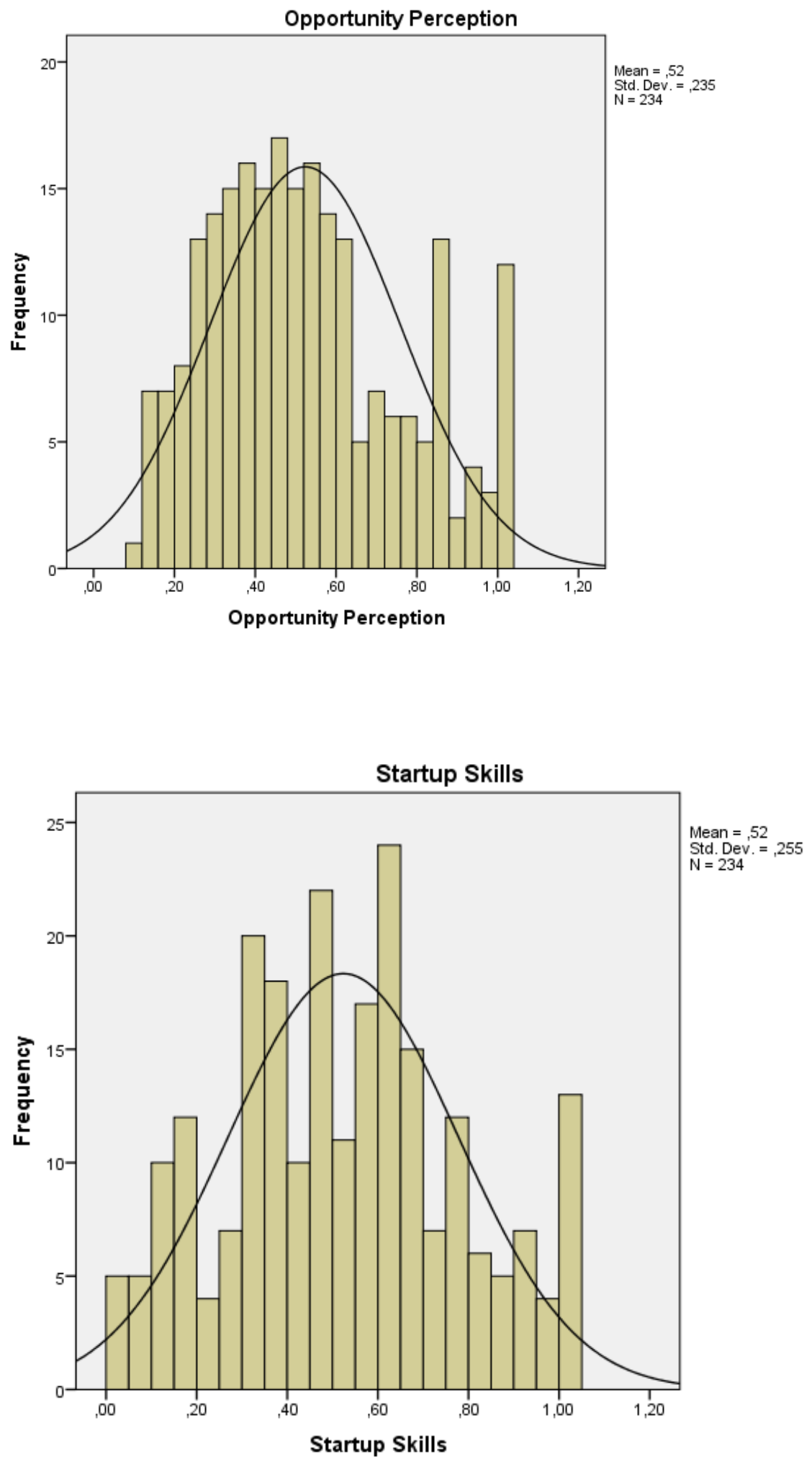


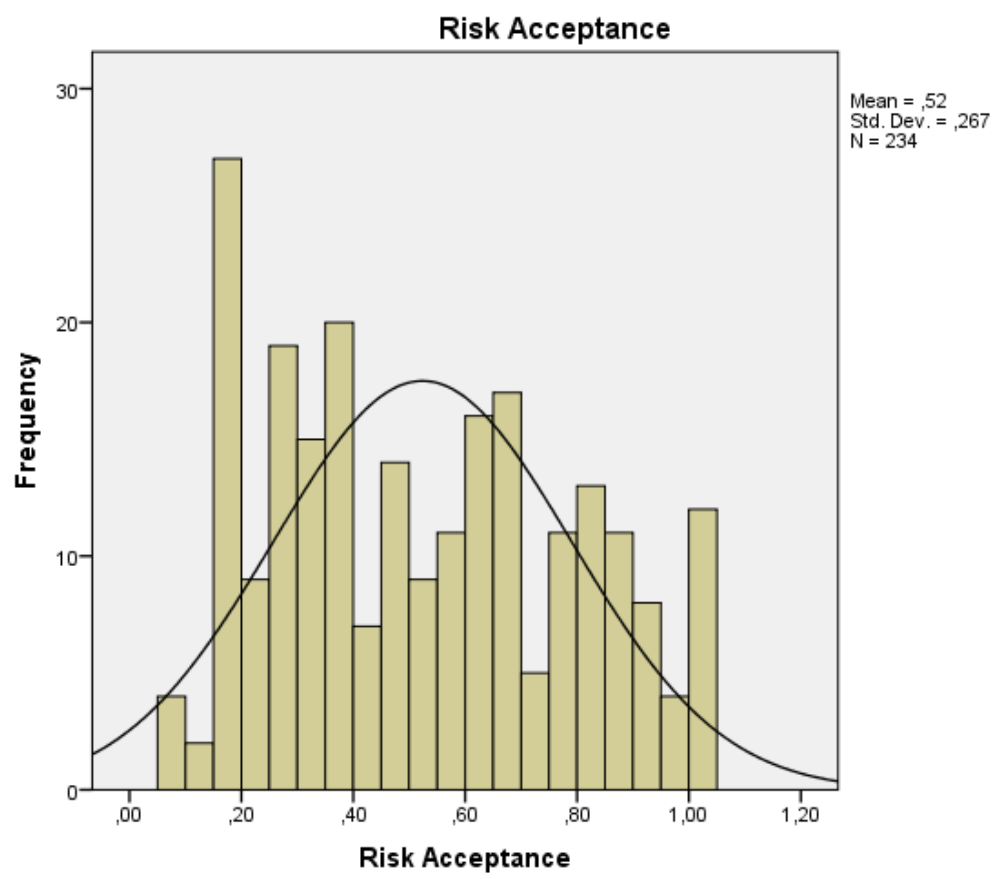




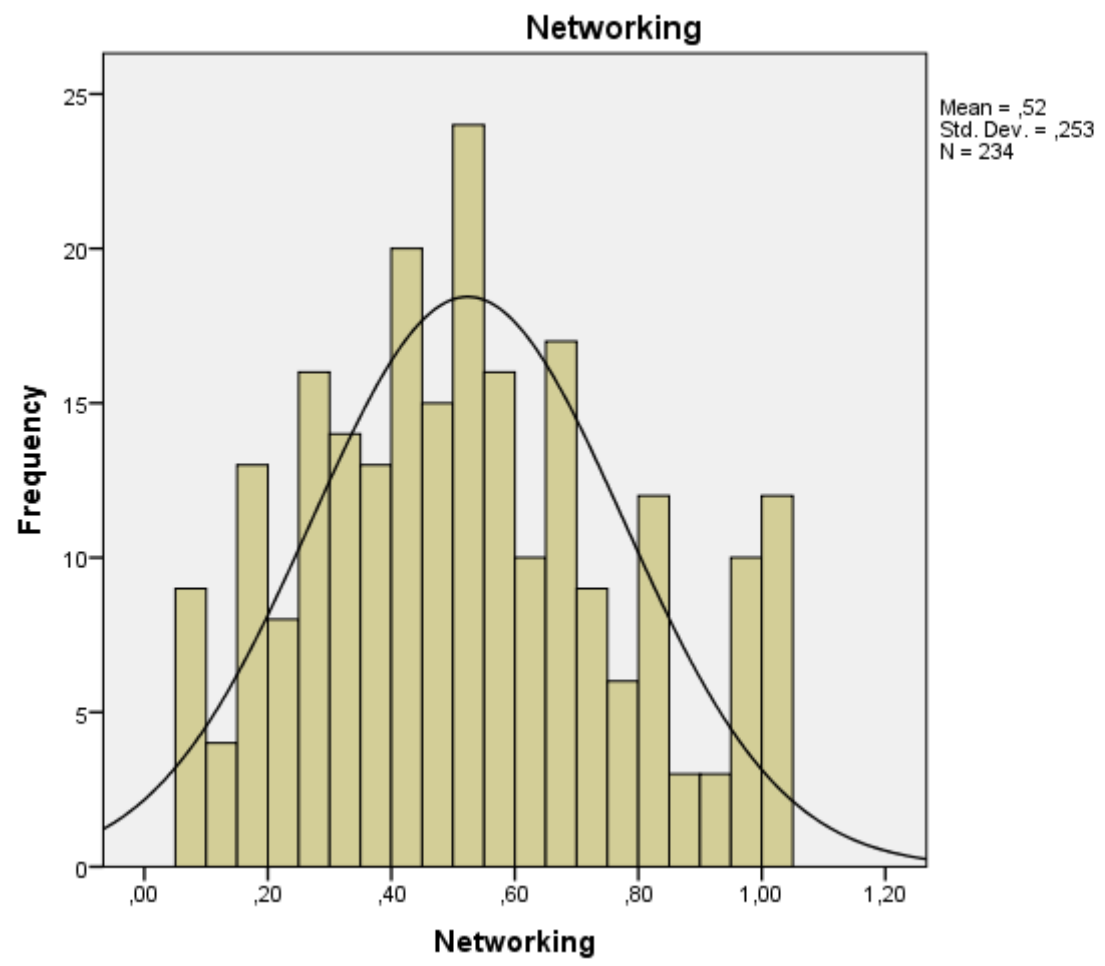



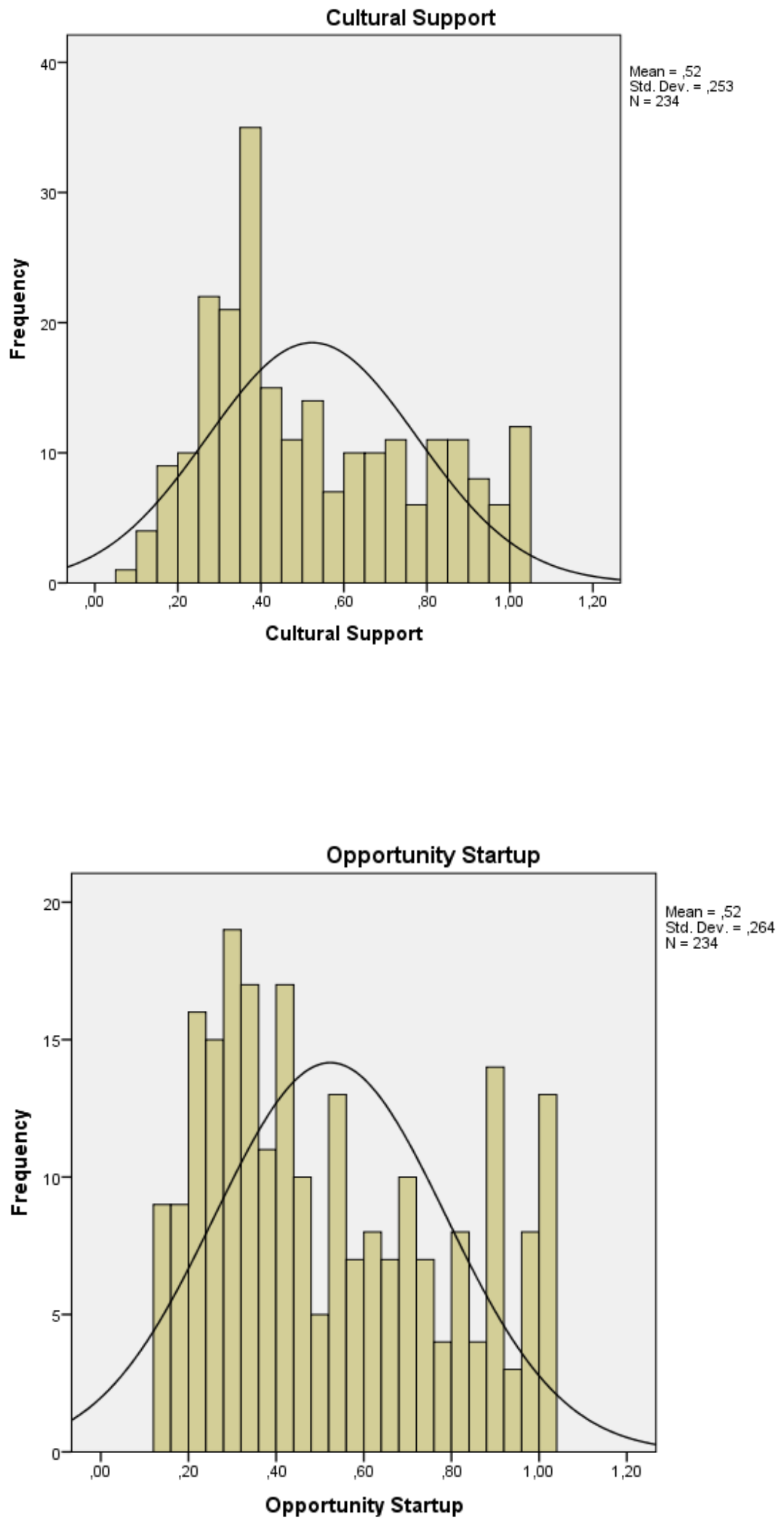

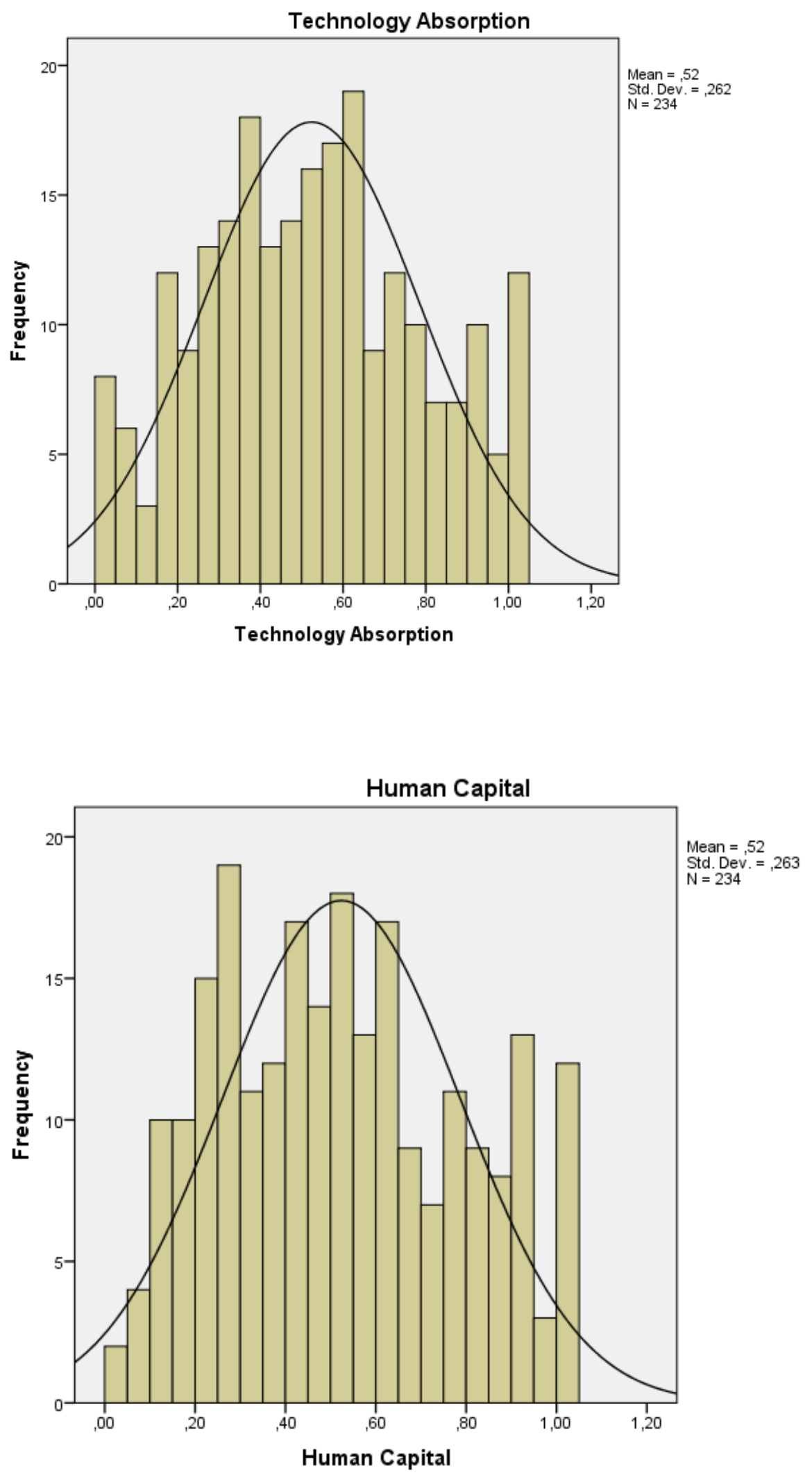

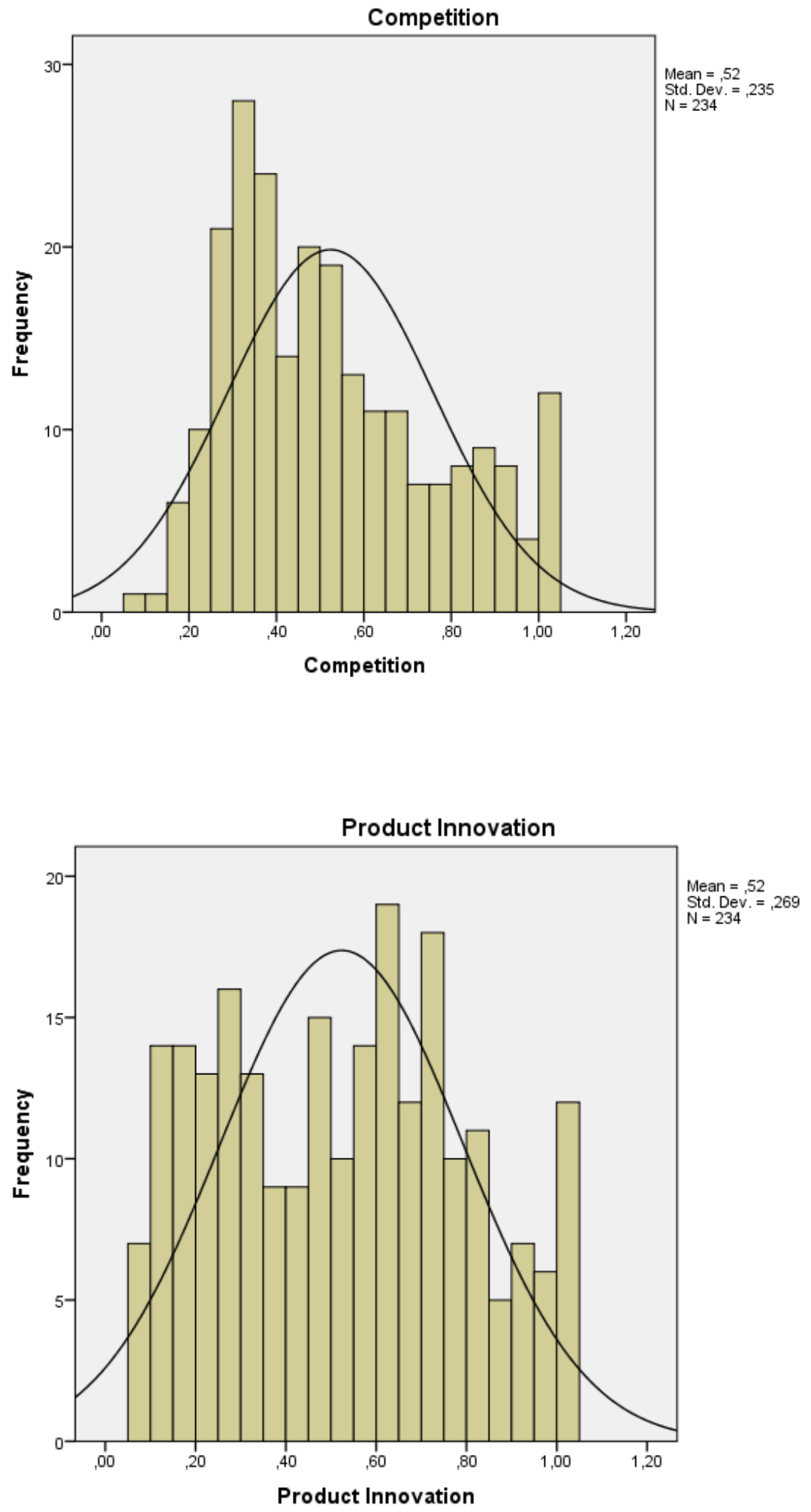

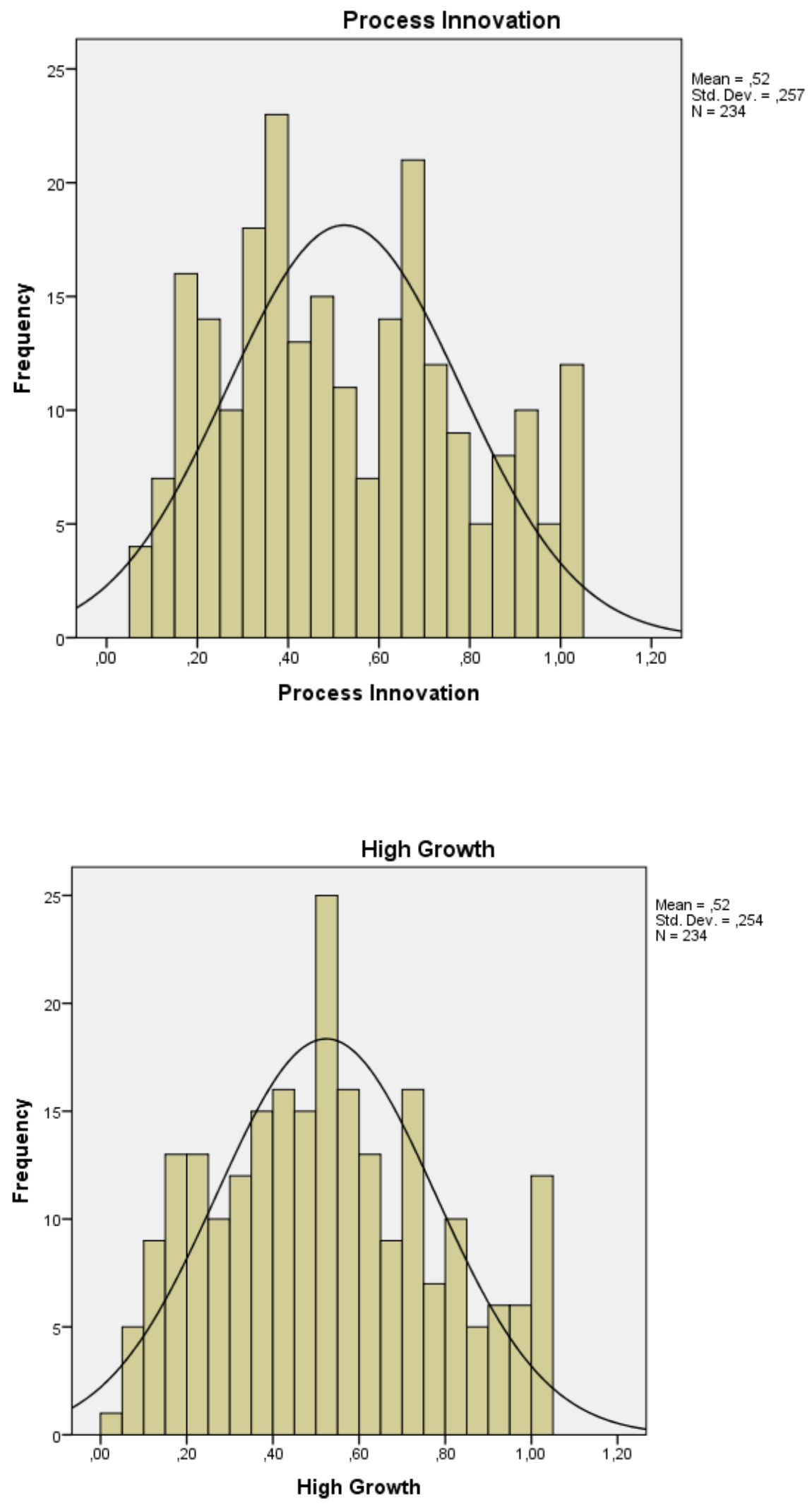

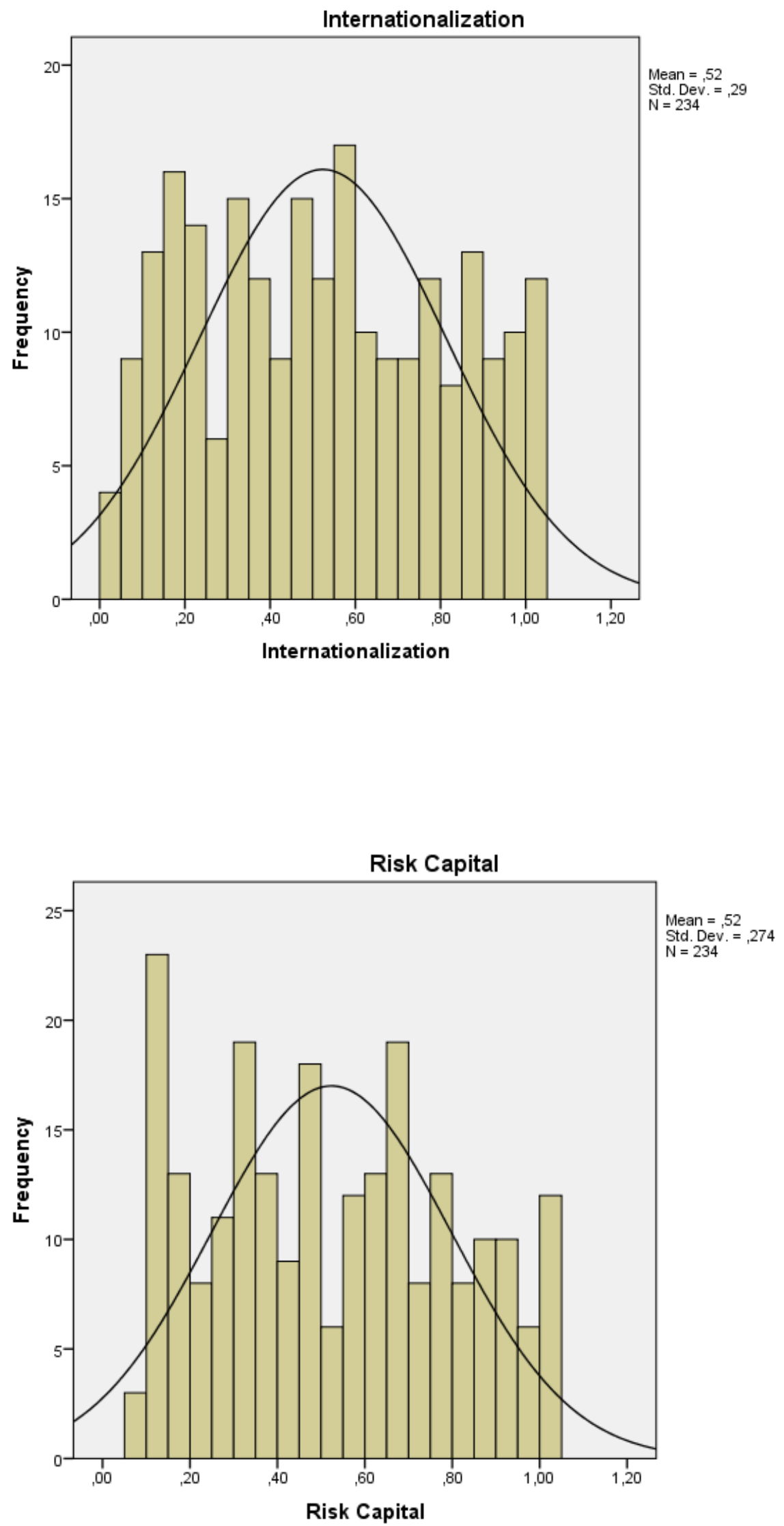